\title{
On Statutory Interpretation and the (Canadian) Rule of Law: Interpretive Presumptions as Boundary Setting
}

\author{
Anver Emon
}

Version Publisher's Version

Citation Anver Emon, "On Statutory Interpretation and the (Canadian) Rule of (published version) Law: Interpretive Presumptions as Boundary Setting" (2015) 3:1 The Theory and Practice of Legislation 45.

Publisher's Statement This is an Accepted Manuscript of an article published by Taylor \& Francis in " The Theory and Practice of Legislation [2015], available online:

http://www.tandfonline.com/[ 10.1080/20508840.2015.1041704.45].

\section{How to cite TSpace items}

Always cite the published version, so the author(s) will receive recognition through services that track citation counts, e.g. Scopus. If you need to cite the page number of the author manuscript from TSpace because you cannot access the published version, then cite the TSpace version in addition to the published version using the permanent URI (handle) found on the record page.

This article was made openly accessible by $U$ of $T$ Faculty.

Please tell us how this access benefits you. Your story matters. 


\title{
ON STATUTORY INTERPRETATION AND THE (CANADIAN) RULE OF LAW: INTERPRETIVE PRESUMPTIONS AS BOUNDARY SETTING
}

\author{
Anver M. Emon*
}

\begin{abstract}
This article brings together debates in statutory interpretation, the rule of law, and legal interpretation. Examining theoretical accounts of the rule of law, the article incorporates a greater attention to questions of interpretivism and the historical context of the interpreter in order to give contextual content to the rule of law. Construing rule of law in terms of fundamental questions about legal interpretation (e.g., discretion, determinacy, objectivity), the article proposes viewing rule of law as a bounded claim space in order to front the boundaries of that space as focal points for rule of law analysis. Reviewing various presumptions of statutory interpretation in Canadian jurisprudence, the article suggests that these presumptions are proxies for the boundary conditions that define, demarcate, and delimit a distinctively Canadian rule of law tradition, thereby showcasing the analytic heft and limited scope of rule of law analysis.
\end{abstract}

\section{Keywords}

Rule of law, legality, history, discretion, legal interpretation, statutory interpretation, Canada.

*Professor and Canada Research Chair in Religion, Pluralism, and the Rule of Law, University of Toronto Faculty of Law. BA, UC Berkeley (1993); JD, UCLA School of Law (1996); MA (University of Texas, 1999); LLM, Yale Law School (2004); PhD, UCLA (History, 2005); SJD, Yale Law School (2009). I wish to acknowledge and thank my colleagues at the University of Toronto Faculty of Law, Yasmin Dawood, Audrey Macklin, Kent Roach, and the Hon Katherine Swinton for reading early drafts of this article and offering helpful comments. I also want to acknowledge Adam Seligman, a colleague and friend, for our numerous discussions about boundaries of difference, and their implications for scholarly research across a range of disciplines. Additionally, I wish to thank Jennifer Komlos, Catherine Stewart, and Michelle Wood for organizing two separate occasions for me to present this paper to lawyers from Ontario's Ministry of the Attorney General, during which I received numerous comments from the audience that helped refine the arguments herein. Paul Gowder offered valuable comments as this paper was nearing completion. Lastly, I want to thank my research assistants Persia Etemadi, Nabila Pirani, and Omar Sirri for their invaluable research and copyediting support. This research was made possible in part by a generous grant from the Foundation for Legal Research. While the above colleagues, participants, students and Foundation helped make this a better article, I remain responsible for any errors herein. 
Across Canadian court rooms, law firms, and government offices, echoes of Elmer Driedger reverberate in the ether of legal debate, dialogue, and judgment. Whatever one might think of the clarity and guidance of Driedger's contextual approach to statutory interpretation (or lack thereof), ${ }^{1}$ those who continue writing in the field offer expansive explanations of what such an approach entails. Ruth Sullivan continued expanding on Driedger's work by editing subsequent editions of his The Construction of Statutes such that, the most recent edition $\left(5^{\text {th }}\right.$, at the time of writing) is entitled Sullivan on the Construction of Statutes. ${ }^{2}$ A monumental treatise, it occupies a regular place in legal libraries across Canada, and is a touchstone for understanding the complex field of statutory interpretation in Canada. ${ }^{3}$

Of particular interest for this article is the way in which Sullivan, throughout her revised edition of this classic treatise, characterizes various principles of statutory interpretation as upholding the "rule of law". This grand phrase appears throughout her treatise, and quite often without explanation or definition. Of course, this is not entirely surprising. The phrase is nearly ubiquitous across a range of legal fields, and is peppered throughout Supreme Court of Canada decisions. The near overabundance but under-specified nature of this phrase is a fact that has not been lost upon commentators. ${ }^{4}$ As theorists and philosophers writing about the rule of law have noted, definitions of the phrase are certainly contested. ${ }^{5}$ Those writing about the phrase offer general definitional principles. As Jeremy Waldron writes, most conceptions of rule of law "give central place to a requirement that people in position of authority should exercise their power within a constraining framework of public norms, rather than on the basis of their own preferences, their ideology, or their own individual sense of right and wrong." 6

\footnotetext{
${ }^{1}$ P-A. Côté and S. Beaulac, 'Driedger's 'Modern Principle' at the Supreme Court of Canada: Interpretation, Justification, and Legitimization' (2005) 40(1) Revue Juridique Themis 131-172.

${ }^{2}$ R. Sullivan, Sullivan on the Construction of Statutes ( $5^{\text {th }}$ edn., LexisNexis, Markham 2008).

${ }^{3}$ Sullivan is not alone in offering key reference sources for legal practitioners and judges in the complex area of statutory interpretation. Pierre-André Côté is a highly respected scholar in the field whose collaborative text on statutory interpretation is an important reference that informs practitioners and courts across Canada, originally prepared in French and in English translation; P-A. Côté (with S. Beaulac and M. Devinat), S. Sacks (tr.), The Interpretation of Legislation in Canada ( $4^{\text {th }}$ edn., Thomson Reuters, Toronto 2011). The focus on Sullivan's text in this article has to do with the "rule of law" frame she adopts throughout her analysis, and which is featured across a range of cases that she addresses.

${ }^{4}$ See for instance, J. Shklar, 'Political Theory and the Rule of Law' in A.C. Hutchinson and P. Monahan (eds.), The Rule of Law: Ideal or Ideology (Carswell, Toronto 1987) 1-16; T. Bingham, The Rule of Law (Penguin Group, London 2010), also admits of ambiguity in the term, though offers an admittedly Anglocentric approach to core concepts he deems significant to the idea.

${ }^{5}$ B.Z. Tamanaha, On the Rule of Law: History, Politics, Theory (Cambridge University Press, New York 2004).

${ }^{6}$ J. Waldron, 'The Concept and the Rule of Law' (2008) 43(1) Georgia Law Review 1-61.
} 
Skeptics of the phrase frame their critique variously, for instance, in terms of the politics underlying rule of law development projects around the world. ${ }^{7}$ Indeed, in place of rule of law some would instead adopt, as a less grandiose synonym, the term "legality". ${ }^{8}$ While the term "legality" certainly does not carry the mighty rhetorical force of "rule of law", whether this turn to "legality" offers greater analytic insight than "rule of law" is a topic that falls outside the scope of this article, and on which this author remains agnostic.

Some might consider the rhetoric of "rule of law" a signal weakness of its analytic potential. Ironically, its rhetorical nature arguably reveals its analytic potential for comparing and contrasting the often particular and contextual conditions that define and demarcate a particular jurisdiction's legal landscape. Philosophically framed rule of law debates take for granted (or worse, ignore) the importance of history (construed broadly here) in identifying the key conditions of legality that characterize a particular legal system, and which check the threat of arbitrary discretion. It is not that philosophers of law reject the relevance of history; indeed, many invoke history as an important element to any inquiry into the conditions of legality. But in doing so, their gesture to history is just that - a gesture in the service of theory, but too often with little content. ${ }^{9}$

7 See for instance, S. Humphreys, Theatre of the Rule of Law: Transnational Legal Intervention in Theory and Practice, Cambridge Studies in International and Comparative Law (Cambridge University Press, Cambridge 2010).

${ }^{8}$ For instance, when writing about the value of legality, Ronald Dworkin notes that "it is sometimes more grandly called, the rule of law". R. Dworkin, 'Hart's Postscript and the Character of Political Philosophy' (2004) 24(1) Oxford Journal of Legal Studies 1-37, 24; See also N. MacCormick, Rhetoric and the Rule of Law: A Theory of Legal Reasoning (Oxford University Press, Oxford 2005) 28, who remarks on Dworkin's above essay and notes his elision of legality and rule of law; for others adopting the term "legality", see S. Shapiro, Legality (Belknap Press, Cambridge 2011); D. Dyzenhaus, Hard Cases in Wicked Legal Systems: Pathologies of Legality ( $2^{\text {nd }}$ edn., Oxford University Press, Oxford 2010); J. Brunée and S.J. Toope, Legitimacy and Legality in International Law: An Interactional Account (Cambridge University Press, Cambridge 2010).

${ }^{9}$ While some may want to insist that aspects of the rule of law are immutable, this would presume that the rule of law has certain core ideas, such as "due process" or some such broad principle. But that abstractness only contributes to the blurring of the term's meaning, as Shklar has noted: Shklar (n 4) 1. Rather, a historical analysis recognizes that these broadly stated, analytically anorexic statements of principle, only take on analytic heft when understood contextually, or in other words historically. Moreover, the mere fact that certain ideas persist over time does not render the rule of law (of features thereof) immutable or ahistorical. Rather historical analysis corroborates their significance in rule of law design, while noting that their salience and meaning is construed in time and space, and thus in historical terms that will vary. But in a more somber note, one cannot ignore how rule of law aspirations often run smack into certain exceptional legal maneuvers by the state in states of emergency. Indeed, the increasing interest in Carl Schmidt's Political Theology and its implications for the post 9/11 American war on terror and surveillance society suggests that historical analysis would pay great dividends if analyzed in relation to presumptions about core notions of the rule of law. See for instance, P. Kahn, Political 
History here is construed broadly as encompassing more than merely a reference to the past, whether in diachronic or synchronic terms. It reflects an attention to context, particularity, and locality. History, in this sense, is an umbrella term meant to draw our attention to the way in which context both gives content to rule of law and limits the scope to which one jurisdiction's rule of law tradition can be generalizable across others. ${ }^{10}$ The turn to history is offered here not as an end-run around those who write about context or particularity, especially concerning more contemporary periods of history. Indeed, it is perhaps not surprising that studies of law concerning the $20^{\text {th }}$ and $21^{\text {st }}$ centuries focus on specific types of contexts or particularities, such as institutions for example, ${ }^{11}$ without framing them in terms of "history". Nevertheless, "history" is utilized here as a broadly construed term of art to incorporate how the discipline of history has grappled with the interpretive turn and has offered different approaches to a study of the particular. ${ }^{12}$ In fact, this article will illuminate how the difficulty in defining rule of law is in large part due to the tendency toward abstract analysis at the cost of a more contextual, particular - broadly historical - inquiry. The resort to "history" thereby recognizes an interdisciplinary potential for shedding light on a set of issues that sometimes sit uneasily at the intersection of (arbitrary) discretion and interpretation in the law.

Examining debates on the rule of law alongside debates on law and interpretation will reveal the contribution of a broad approach to history, namely to set the boundaries of what counts as law and legal argument in a given legal system. ${ }^{13}$ A significant concern that seems to underlie rule of law debates is the concern with discretion, in particular arbitrary discretion. The possibility of government action based on will as opposed to reason or reasoned deliberation is a keystone that reveals the undercurrent of rule of law debates. An analysis of various theorists writing on rule of law will illustrate that rule of law concerns about discretion either implicitly or explicitly invoke questions about

Theology: Four New Chapters on the Concept of Sovereignty (Columbia University Press, New York 2011).

${ }^{10}$ For an example of a diachronic historical account of Islamic law as a rule of law tradition, see A.M. Emon, Religious Pluralism and Islamic Law: Dhimmis and Others in the Empire of Law (Oxford University Press, Oxford 2012).

${ }^{11}$ See for example, C.R. Sunstein and A. Vermeule, 'Interpretation and Institutions' (2003) 101(4) Michigan Law Review 885-991.

${ }^{12}$ G.M. Spiegel, 'History, Historicism, and the Social Logic of the Text' in V.E. Bonnell and L. Hunt (eds.), The Past as Text: The Theory and Practice of Medieval Historiography (Johns Hopkins University Press, Baltimore 1997) 3-28; V.E. Bonnell and L. Hunt (eds.), Beyond the Cultural Turn (University of California Press, Berkeley 1999).

13 The idea of boundaries as used herein is meant to help "map" the rule of law as a claim space. But it shares much with other expressions used to delineate the limits or conditions of legal analysis. For instance, when writing about purposive analysis, Sullivan invokes the idea of "norms of plausibility", which she describes as assumptions not only about the words a speaker used, but also "about the world: how things work, what counts as a fact, which effects flow from which causes, which effects are desirable, what makes sense and so on." Sullivan, Construction of Statutes, 273 
interpretation. Reading those rule of law debates in light of other, related debates on law and interpretation will reveal how thinking historically enhances our appreciation of how the scope of legal indeterminacy is limited and why. As such, scholarship in the fields of rule of law and law and interpretation together reveal how history can inform and give greater analytic heft to rule of law as a term of art. Indeed, to the extent this analysis offers something distinctive to the already extensive scholarship on rule of law and legal interpretation, it undercuts the value of applying terms like rule of law or legality as general concepts that can capture legal realities across different polities and jurisdictions without due attention to the particularities and context - i.e., history - of a legal tradition or system.

To illustrate the contribution history can make, this article will examine various topics in Canadian statutory interpretation jurisprudence to show how presumptions of interpretation are pretexts for certain boundary conditions that constitute a Canadian rule of law system. Section A of this article will examine rule of law debates pitched at a highly philosophical level to identify whether and to what extent a historical analysis is presumed or anticipated. Section B will identify the way in which rule of law concerns about (arbitrary) discretion are analogous to the kinds of concerns that arise in debates on the interpretive turn in the law. Section $\mathrm{C}$ will address how the interpretive turn in law invites a historical approach to objectivity and determinacy in the law. Moreover, it will address how the historically oriented trope of "boundaries" can help reveal the defining characteristics of a rule of law tradition, and thereby give analytic weight to rule of law as an idea. Section D will examine such boundaries in the context of Canadian jurisprudence on statutory interpretation. As a review of judicial decisions will reveal, the statutory principles that guide interpretation all too often serve as proxies for certain boundary conditions that define and delimit a distinctively Canadian rule of law claim space. The theoretical take-away of this analysis is to suggest that rule of law is better appreciated as a claim space within which arguments of justice are made. As a claim space, it is defined and bounded. These boundaries define a rule of law system as a claim space; as such, these boundaries constitute the conditions of legality and serve as backdrop to the principles of statutory interpretation analyzed herein.

\section{A. RULE OF LAW THEORY: GESTURES TO THE HISTORIC}

When theorists write about the conditions under which rule of law or legality prevail, they often gesture to something empirically verifiable, conventional, or in some sense part of the tradition of the relevant legal system. That 'something' has to do with context, particularity, or some sociological reality that exists. For the purposes of this article, the term "history" captures the need to reflect on that particularity so as to give analytic heft to the idea of the rule of law. But as will be shown below, philosophers writing about the rule of law all too often make small gestures to history without explaining what they mean or how to ascertain that relevant history. Their failure to expound upon their gestures to history limits the 
analytic content of the rule of law and gives it the appearance of a general, highly exportable principle, when in fact it is not. ${ }^{14}$

For instance, H.L.A. Hart wrote about his rule of recognition and its role in delineating what the law is and where it can be found. Though Hart did not extensively address the rule of law at any length in his treatise, it would not be farfetched to characterize his concept of law, and in particular his rule of recognition, as a blueprint for the rule of law. Indeed as his biographer Nicola Lacey has suggested, "we might see the very project of legal positivism as an essential plank in the intellectual and practical infrastructure of the rule of law." 15 According to Hart, the rule of recognition specifies "some feature or features possession of which by a suggested rule is taken as a conclusive affirmative indication that it is a rule of the group." "Importantly, he described it as reflecting a social practice account of the law. As Hart wrote in the Postscript to the second edition: "The account I have given... has become known as 'the practice theory' of rules because it treats the social rules of a group as constituted by a form of social practice comprising both patterns of conduct regularly followed by most members of the group and a distinctive normative attitude to such patterns." 17

Elsewhere, Hart's writings gesture toward the historical, though he rarely expounds upon the implications for his theoretical analysis. In his 1957 Holmes Lecture, he addressed the separation of law and morals, but resituated the question at the level of a "legal system considered as a whole". ${ }^{18}$ In his lecture, he recognized that a legal system reflects in part the kinds of values that a people have, hold, and share. When characterizing these sorts of values, he stated:

The world in which we live, and we who live in it, may one day change in many different ways; and if this change were radical enough not only would certain statements of fact now true be false and vice versa, but whole ways of thinking and talking which constitute our present conceptual apparatus, through which we see the world and each other, would lapse. We have only to consider how the whole of our social, moral, and legal life, as we understand it now, depends on the contingent fact that though our bodies do change in shape, size and other physical properties they do not do this so drastically nor with such quicksilver rapidity and irregularity that we cannot identify each other as the same persistent individual over considerable spans of time. Though

\footnotetext{
${ }^{14}$ See generally, Humphreys (n 7).

15 N. Lacey, 'H.L.A. Hart's Rule of Law: The Limits of Philosophy in Historical Perspective' (2007) 36 Quaderni Fiorentini 1203-1224, 1204. As Lacey notes, though, Hart more expressly addressed rule of law themes in his 1957 Holmes lecture published in the Harvard Law Review, which will be addressed below.

${ }^{16}$ H.L.A. Hart, The Concept of Law (2 $2^{\text {nd }}$ edn., Clarendon Press, Oxford 1994) 94.

${ }^{17}$ H.L.A. Hart, "Postscript," The Concept of Law ( $2^{\text {nd }}$ edn., Clarendon Press, Oxford 1994) 255.

${ }^{18}$ H.L.A. Hart, 'Positivism and the Separation of Law and Morals' (1958) 71(4) Harvard Law Review 593-629, 621.
} 
this is but a contingent fact which may one day be different, on it at present rest huge structures of our thought and principles of action and social life. ${ }^{19}$

Whether change occurs as slowly as Hart suggested or more quickly, what mattered most to Hart was that this systemic approach to morality was consistent with his social practice approach to law. Hart's presumption about morality assumed change over long periods of time, and as such did not affect substantially his theory of law in the now. ${ }^{20}$ In other words, change (and by implication history) certainly affects the intelligibility of the law as a whole or a particular legal rule; however given the slow, long-term pace of such change, it is not theoretically significant for Hart's positivist account of the law. ${ }^{21}$

In their reflections on Hart's theory of law, scholars have commented upon the relationship between his practice theory of rules and the importance of historical analysis. For instance, Leslie Green has noted that according to Hart, law is a "union of social rules" and that the rule of recognition "simply exists as a matter of social fact or it does not". ${ }^{22}$ Situating Hart's entire argument amidst larger trends in the social sciences (and presumably the humanities too), Green went further to suggest that Hart's general account of the law reflects the latter's recognition of the contextual, historical nature of law and its development. Discounting for the all-too-trendy attitudes in the academy about "constructivism", Green argued that "Hart's theory places law firmly in history. According to him, that there is law at all follows wholly from the development of human society, a development that is intelligible to us, and the content of a particular legal system is a consequence of

\footnotetext{
${ }^{19}$ ibid 622.

${ }^{20}$ Incidentally, Hart's approach to morality and change at this systemic level reveals a type of long-term historical change that resembles French historian Fernand Braudel's longue durée, which focuses less on events or the political history of "great people" (histoire événementielle, history of events), and more on systemic structural change over longer periods of time. Associated with that approach is the "history of mentalities" (histoire des mentalités), an approach to historical analysis that charts changes across the values and ideas of a people, or what some might consider "cultural history". For historiographic debates about the longue durée, histoire événementielle, and histoire des mentalité, see L. Hunt, 'French History in the Last Twenty Years: The Rise and Fall of the Annales Paradigm' (1986) 21 Journal of Contemporary History 209-224; P. Burke, 'Strengths and Weaknesses of the History of Mentalities' (1986) 7(5) History of European Ideas 439-451. The fact that Hart would find such large scale, long-term approaches to morality and history relatively irrelevant for his theory of law may indeed reflect more about Hart's presumptions about history.

${ }^{21}$ According to Hart, those who live together in a legal system "cherish the humble aim of survival in close proximity to our fellows" Hart (n 18) 623 (emphasis added). The humility underlying this systemic approach to morality lies in stark contrast, according to Hart, to the natural law jurists who would "dictate a further necessary content to a legal system", which Hart believes assumes too much of the law and of those who live under it. Hart (n 18) 623.

${ }^{22}$ L. Green, 'The Concept of Law Revisited' (1996) 94(6) Michigan Law Review 1687$1717,1693$.
} 
what people in history have said and done." ${ }^{23}$ Consequently, to envision the rule of recognition as a social fact, and the law more broadly as reflective of social practices, is to invoke the limiting conditions of a given social practice in time and space as constitutive of the conditions of legality.

Lacey, on the other hand, has noted that Hart's approach to legal philosophy was "distinctively analytic rather than historical. Though keenly aware of the power of political circumstances in shaping ideas, [Hart] was skeptical of more general claims about the contextual dependence of theories." ${ }^{24}$ This is not to suggest that Hart displaced the historical or sociological by prioritizing the analytic, nor that a more robust account of history in his theory would be inappropriate. Rather, this is merely to note that his analytic approach gestured to the historical and sociological; but that is all. Moreover, as Lacey has argued, Hart's lack of interest in historical and institutional contextualization "marks a certain limit to the insights provided by his legal and political philosophy.",25

In his important response to Hart's Postscript, Hart's principal critic Ronald Dworkin considered the political and legal philosophies that frame the rule of law. But in doing so, he also merely gestured to the historical without much more. In a succinctly written statement, Dworkin wrote:

Legality is engaged, we might say, when political officials deploy the state's coercive power directly against particular persons or bodies or groups - by arresting or punishing them, for example, or forcing them to pay fines or damages. Legality insists that such power be exercised only in accordance with standards established in the right way before that exercise. ${ }^{26}$

Importantly, Dworkin argued that legality "is sensitive in its application, to a far greater degree than is liberty, equality or democracy, to the history and standing practices of the community which aims to respect the value, because a political community displays legality, among other requirements, by keeping faith in certain ways with its past." 27 The implication of this connection between legality and history is to require an attention to continuities and discontinuities in legal analysis to assess violations of legal limits, and thus to reveal the boundaries of a legal system: "So any even moderately detailed account of what legality requires in concrete terms in some particular jurisdiction must attend very carefully to the special institutional practices and history of that jurisdiction." 28

Dworkin's gesture to history certainly recognizes the way in which even the transcendent ideals or values of a legal system must nonetheless take shape in a

\footnotetext{
23 ibid 1691.

${ }^{24}$ N. Lacey, 'Philosophy, Political Morality and History: Explaining the Enduring Resonance of the Hart-Fuller Debate' (2008) 83 New York University Law Review 10591087, 1061.

${ }^{25}$ ibid 1062.

${ }^{26}$ Dworkin (n 8) 24.

27 ibid 35 (emphasis added).

28 ibid 35 (emphasis added).
} 
given institutional setting. But this turn to history does not, and for him should not, displace a philosophical inquiry that transcends the particulars of a given historical tradition. ${ }^{29}$ Indeed, it would seem that for Dworkin, the historical is more instrumental, if not decorative, to his more substantive engagement with legal philosophy and the tendency toward the transcendent, the general, and the abstract.

In an oft-discussed and cited article, Joseph Raz offered an account of rule of law that is hardly inspiring (at least to those with liberal democratic commitments), but which reflects his interest in the analytic potential of the phrase. For Raz, the rule of law arises from a "basic intuition" that "the law must be capable of guiding the behavior of its subjects." ${ }^{30}$ From this basic intuition, Raz argues that various rule of law principles follow. He offers a sample of those principles, the list of which can certainly be compared and contrasted to those offered by Lon Fuller in his The Morality of Law. ${ }^{31}$ Furthermore, the rule of law is not a zero-sum game in which it either does or does not exist, but rather "is a political ideal which a legal system may lack or may possess to a greater or lesser degree." 32 Of particular significance, though, is that Raz's account is a minimal one, designed so as to preclude confusing rule of law with other ideals. Indeed, as Raz remarked, the rule of law "is not to be confused with democracy, justice, equality (before the law or otherwise), human rights of any kind or respect for persons or for the dignity of man." 33

The minimal account serves Raz's larger aim, namely to limit the rhetorical tendencies among those who invoke the rule of law. He recognized the rhetorical function of the phrase as a "slogan" for those committed to certain ideals and ideologies. ${ }^{34}$ In contrast, Raz's bare account of the rule of law is stripped of ideals that seem to influence contemporary advocates of rule of law development, for instance. ${ }^{35}$ Indeed, in a particularly provocative set of sentences, he revealed just how narrowly he construed rule of law:

A non-democratic legal system, based on the denial of human rights, on extensive poverty, on racial segregation, sexual inequalities, and religious persecution may, in principle conform to the requirements of the rule of law better than any of the legal systems of the more enlightened Western democracies. This does not mean that it will be better than those Western

\footnotetext{
${ }^{29}$ ibid 35-36.

${ }^{30}$ J. Raz, 'The Rule of Law and its Virtues' in The Authority of Law: Essays on Law and Morality (Reprint 1994, Clarendon Press, Oxford 1979) 210-232, 214.

${ }^{31}$ For Raz's principles see ibid 214-19. For Lon Fuller's eight principles, see L.L. Fuller, The Morality of Law (Revised edn., Yale University Press, New Haven 1965).

${ }^{32} \operatorname{Raz}(\mathrm{n} 30) 211$.

${ }^{33}$ ibid. See also, J. Waldron, 'The Concept and the Rule of Law' (2008) 43(1) Georgia Law Review 1-61,3, who counts rule of law as "one of a cluster of ideals constitutive of modern political morality, the others being human rights, democracy, and perhaps also the principles of free market economy".

${ }^{34} \operatorname{Raz}(\mathrm{n} 30) 210$.

${ }^{35}$ See generally, Humphreys (n 7).
} 
democracies. It will be an immeasurably worse legal system, but it will excel in one respect: in its conformity to the rule of law. ${ }^{36}$

For the purposes of this analysis, Raz's specific principles of the rule of law are less interesting than the language he used to frame how they are derived. Specifically, he states: "Many of the principles which can be derived from the basic idea of the rule of law depend for their validity or importance on the particular circumstances of different societies." ${ }^{37}$ Indeed, this gesture (and a mere gesture at that) parallels the gestures made by Hart and Dworkin when reflecting on the contextual or historical content that informs the rule of recognition or the conditions of legality. But as mere gestures, they do not offer much guidance as to what that kind of history should look like. What counts as the appropriate particular circumstances that give content to the basic idea of the rule of law and the principles derived therefrom? What sorts of social facts ought we to consider when trying to describe a legal system's "rule of recognition"? How is it that legality is more attentive to the history of a particular community than values such as democracy, and what does that imply about how a particular interpreter in a legal community can or ought to approach an issue requiring legal interpretation? In these three philosophical encounters with the rule of law, we see the tendency toward philosophical abstraction coupled with mere gestures toward an empirically verifiable "there" that is assumed for purposes of driving a theoretical analysis. But in what sense does this offer any sort of clarity to a contextually situated interpreter who must make sense of the terrain of legality prior to making or executing a legal determination? The use of "terrain" is intentional here, if only to suggest that the analytic thrust of rule of law as a phrase may be better appreciated if situated within an analytic space, thereby putting in stark relief the importance of boundaries that include, exclude, and ultimately define the peripheries of what counts as intelligible legal argument.

\section{B. RULE OF LAW CONCERNS ABOUT DISCRETION: INTERPRETIVISM AND THE TURN TO HISTORY}

As noted at the outset of this article, the primary concern underlying rule of law debates has to do with arbitrary discretion in official decision-making. The possibility that government action may be premised on the mere will of an official as opposed to reasoned deliberation that is publicly accessible and verifiable lies at the heart of rule of law debates. This is not to say that all discretion, per se, runs contrary to the rule of law. For instance, administrative law debates about standards of judicial review implicitly (if not explicitly at times) recognize the importance of granting administrators of state agencies some degree of discretion. The rule of law issue, so to speak, is how much discretion is too much discretion. The analysis below will show how theorists such as Hayek, Hart, and Dworkin

\footnotetext{
${ }^{36} \operatorname{Raz}(\mathrm{n} 30) 211$.

37 ibid 214.
} 
have either implicitly or explicitly linked their interest in rule of law to concerns about discretion, which in turn invoke (or at least ought to invoke) a robust interest in the context of interpretation (and thus history) in setting the boundaries of discretionary judgment.

When F.A. Hayek wrote about the rule of law, he did so as part of a larger aim to check against expansive government reach into the realm of what he considered private affairs. He characterized the rule of law as a check against government exercise of arbitrary power. In fact, he stated quite explicitly: "The great aim of the movement against arbitrary power was, from the beginning, the establishment of the rule of law." ${ }^{38}$ For Hayek, rule of law is a "meta-legal doctrine or political ideal" that concerns what "the law ought to be". ${ }^{39}$ Hayek's approach to the rule of law, though, is arguably framed by his particular worry about the size, scope, and reach of the welfare state in continental Europe. For instance, Francis Fukuyama has remarked that "Hayek was a great enemy of a powerful state, not just of Sovietstyle Communist dictatorships but also of European social democracies that sought to achieve 'social justice' through redistribution and regulation." 40 Likewise, Stephen Humphreys, in his masterful analysis of rule of law and development, has shown that Hayek took aim at the

general shift towards welfare in the 1930s...the still new European welfare state and the New Deal, on one hand, the Soviet and National Socialist regimes, on the other. Hayek linked these vastly divergent systems together by identifying a position all shared, in his view - that the 'greater complexity' of modern society rendered inevitable a larger government role in steering the economy. $^{41}$

Of particular interest here is Hayek's narrow concern with "discretion" as a threat to the rule of law. Hayek offered three different accounts of "discretion" in order to clarify the exact nature of his concern for the rule of law. The first has to do with institutions of government (e.g., legislature) delegating authority to an agency of government (e.g., executive administration). Hayek was not particularly worried about this exercise of discretion since it generally applied to the government's own resources. ${ }^{42}$ The second involves the judge who must interpret and apply the law. Again, Hayek was not worried about this particular exercise of discretion as he believed it involved the application of rules and not judicial will, and as such did not threaten the rule of law that he valued. ${ }^{43}$ The third form of discretion, which was the narrow focus of his critique, had to do with the increased

${ }^{38}$ F.A. Hayek, 'The Constitution of Liberty' in R. Hamowy (ed.), The Collected Works of F.A. Hayek, vol. 17 (University of Chicago Press, Chicago 2011) 288.

${ }^{39}$ ibid 311.

${ }^{40}$ F. Fukuyama, The Origins of Political Order: From Prehuman Times to the French Revolution (Farrar, Straus and Giroux, New York 2011) 253.

${ }^{41}$ Humphreys (n 7) 78.

${ }^{42}$ Hayek (n 38) 321.

${ }^{43}$ ibid 320-21. 
scope of government administration in general: "The problem of discretionary powers as it directly affects the rule of law is not a problem of the limitation of the powers of particular agents of government but of the limitation of the powers of the government as a whole. It is a problem of the scope of administration in general." 44

Of particular interest here is that Hayek dismissed judicial interpretation of the law as a threat to the rule of law. His dismissiveness of legal interpretation, though, was premised upon certain formalist assumptions about the law. For instance, he wrote:

The task of the judge is to discover the implications contained in the spirit of the whole system of valid rules of law or to express as a general rule, when necessary, what was not explicitly stated previously in a court of law or by a legislator. That this task of interpretation is not one in which the judge has discretion in the sense of authority to follow his own will to pursue particular concrete aims appears from the fact that his interpretation of the law can be, and as a rule is, made subject to review by a higher court. ${ }^{45}$

Hayek's description of what a judge does - namely to discover implications that are already there in the general body of law, though not always made explicit reveals an understanding of legal reasoning that was perhaps prevalent among late nineteenth and early twentieth century American legal scholars. That approach to the law, though, has lost considerable persuasive power in light of critiques by legal realists, ${ }^{46}$ not to mention hermeneutic theorists of law and interpretation. ${ }^{47}$

As others writing in legal philosophy and broadly about rule of law would suggest, Hayek's archaeological formalism cannot be sustained. For instance, Hart recognized that such formalist views of judicial reasoning do not fully capture the extent to which a judge exerts a certain "will" in his or her decision-making. ${ }^{48}$ In his Postscript to The Concept of Law, Hart addressed the issue of judicial discretion in terms that challenge Hayek's view. Moreover, Hart's analysis exposed discretion as the conceptual link between the two fields of rule of law and legal interpretation. He described his own account of judicial discretion as follows:

\footnotetext{
${ }^{44}$ ibid 321 (emphasis added).

45 ibid 320 (emphasis added).

${ }^{46}$ B.Z. Tamanaha, A General Jurisprudence of Law and Society (Reprint 2006, Oxford University Press, Oxford 2001) 47.

${ }^{47}$ See, for instance, R.J. Coombe, "Same as it Ever Was': Rethinking the Politics of Legal Interpretation' (1989) 34 McGill Law Journal 604-652, for a useful survey of the literature. Moreover, though Dworkin is often associated with a "right answer thesis", his argument is embedded within a larger interpretive account of judicial decision-making, and so does not seem to suffer from the same sort of formalism that Hayek's remarks above reveal. On Dworkin's interpretive account of the law, see R. Dworkin, Law's Empire (Belknap Press, Cambridge 1988).

${ }^{48}$ He lays blame for this particular notion of formalism on Blackstone. See Hart (n 18) 593-629, 610-11.
} 
[I]n any legal system there will always be certain legally unregulated cases in which on some point no decision either way is dictated by the law and the law is accordingly partly indeterminate or incomplete. If in such cases a judge is to reach a decision and is not...to disclaim jurisdiction or to refer the points not regulated by the existing law to the legislature to decide, he must exercise his discretion and make law for the case instead of merely applying already preexisting settled law. ${ }^{49}$

This is not to suggest that in making law the judge exerts an unchecked discretion. For Hart, though judicial interpretation involves "making law", the judicial interpreter is nevertheless guided or bounded by limiting conditions that the law imposes upon the interpretive endeavor. As Hart wrote: "not only are the judge's powers subject to many constraints narrowing his choice from which a legislature may be quite free, but since the judge's powers are exercised only to dispose of particular instant cases he cannot use these to introduce large-scale reforms to new codes. So his powers are interstitial as well as subject to many substantive constraints." ${ }^{, 50}$

\section{Dworkin, Fit, and the Historical}

Perhaps no theorist is more associated with an interpretivist account of legal judgment than Ronald Dworkin. In such acclaimed studies as Taking Rights Seriously and Law's Empire, Dworkin set out his interpretive account of law, namely of law's integrity. So much has been written about Dworkin's oeuvre that little that is novel will be said here. Rather, of specific interest here is how his theory of legal interpretation intersects important rule of law debates about limiting discretionary judgment.

At the outset of his Law's Empire, Dworkin asked how the law can "command when the law books are silent or unclear or ambiguous?" For Dworkin, the answer has everything to do not only with interpretation, but how and what we interpret: "legal reasoning is an exercise in constructive interpretation, that our law consists in the best justification of our legal practices as a whole, and that it consists in the narrative story that makes of these practices the best they can be." 51 Specifically, Dworkin disciplined his interpretive enterprise by reference to a notion of "fit". He wrote:

Convictions about fit will provide a rough threshold requirement that an interpretation of some part of the law must meet if it is to be eligible at all. Any plausible working theory would disqualify an interpretation of our own law that denied legislative competence or supremacy outright or that claimed a

\footnotetext{
${ }^{49}$ Hart (n 17) 272.

${ }^{50}$ ibid 273 (underlining added).

${ }^{51}$ Dworkin (n 47) vii.
} 
general principle of private law requiring the rich to share their wealth with the poor. That threshold will eliminate interpretations that some judges would otherwise prefer, so the brute facts of legal history will in this way limit the role any judge's personal convictions of justice can play in his decisions. Different judges will set this threshold differently. But anyone who accepts law as integrity must accept that the actual political history of his community will sometimes check his other political convictions in his overall interpretive judgment. ${ }^{52}$

In this extended quotation from Dworkin's monumental work on interpretation, the requirement of fit is especially intriguing for this analysis. He variously defined fit by reference to the legal history or the political history of a community. More importantly, he seemed to suggest that whatever this history is and whatever threshold it reflects, it serves as a check against a judge's personal, subjective convictions.

As significant as "fit" is for Dworkin's theory, he did not fully develop it. Indeed, in his subsequent response to Hart's Postscript, Dworkin recognized the need for greater detail about what "fit" involves:

I said there [Law's Empire], for example, that...a constructive interpretation aims both to fit and to justify the data. I warned that 'fit' and 'justification' are only names for two rough dimensions of interpretation, and that further refinement would require a more careful analysis of other, discrete political values through which to understand these dimensions more thoroughly.... ${ }^{53}$

As Dworkin remarked later in that essay, "procedural fairness" is the "nerve of the dimension of fit". ${ }^{54}$ In one sense, Dworkin simply substitutes one ambiguous phrase for another. In his Justice for Hedgehogs, Dworkin used a family dispute analogue to explain how the principles of procedural justice are "special structuring principles that separate law from the rest of political morality". ${ }^{55}$ Imagine a dispute between a brother and a sister, where one promises to take the other to a music concert but later reneges in order to take someone else who offers the promise of young romance. Dworkin queried how a parent might resolve this dispute. A range of questions might arise about how the parent decided similar questions in the past, or about attitudes about coercive authority and how it ought to be applied in the given instance. Dworkin argued that to answer the various questions he posed was to construct a "distinct institutional morality: a special morality governing the use of coercive authority within your family." 56

\footnotetext{
${ }^{52}$ ibid 255 (emphasis added).

${ }^{53}$ Dworkin (n 8) 25.

54 ibid 25.

55 R. Dworkin, Justice for Hedgehogs (Belknap Press, Cambridge 2011) 413.

${ }^{56}$ ibid 408.
} 
The principal aim of this example is to illuminate the implications of Dworkin's general critique of the Positivist's separation thesis between law and morality. Adopting a "one-system" approach, Dworkin argued that law and morality are part of any legal inquiry, which is itself a special branch on the tree of political morality. The distinctive features of law, according to Dworkin, "will center on the phenomenon of institutionalization." 57 In the case of the family, that institutional phenomenon involves asking two distinct questions: "What conditions hold, now, on the use of coercive authority within the family, given its distinct history? What conditions would a better family history, reflecting better answers to questions... have produced?"58 For Dworkin, the distinction between these two questions cannot be characterized in terms of the distinction between law and morality; both are infused with moral content, and thus speak to his overall critique of the tendency to separate law and morality.

Significantly for the purpose of this analysis, the reference to the family's history of coercive authority reveals the importance of a certain historical accounting to reveal the conditions of legality (i.e., rule of law) that prevail, without suggesting that what they are is also what ought to be. In Justice for Hedgehogs, Dworkin thereby provided greater insight into what he once meant by "fit", the significance of "fit" for his notion of "legality", and how an inquiry into "legality" necessarily demands an attention to a type of historical inquiry, which for Dworkin is characteristically institutional in nature.

\section{Institutional Turn as Historical}

Dworkin's turn to the institutional in his interpretive approach to law reflects the constitutive role history can play in defining a particular rule of law tradition. The turn to institutions offers an important meeting point for debates on rule of law, legal interpretation, and history. Scholars such as Cass Sunstein and Adrian Vermeule have informed their approach to law and legal interpretation by reference to what is called across different disciplines the "institutional turn". 59 This scholarly approach to law and legal interpretation presses for a philosophy of law and legal interpretation that incorporates a very particular, contemporary,

\footnotetext{
57 ibid 405. See also H. Baxter, 'Dworkin's 'One-System' Concept of Law and Morality' (2010) 90 Boston University Law Review 857-862, 861, who addresses Dworkin's institutional turn.

${ }^{58}$ Dworkin (n 55) 408.

${ }^{59}$ Sunstein and Vermeule (n 11). Scholars in other disciplines are also examining whether and to what extent greater attention to institutions can enhance the scholarship in fields that have tended toward the philosophically abstract for too long or with limited analytic payoffs. In political philosophy, see V. Bader and E.R. Engelen, 'Taking Pluralism Seriously: Arguing for an Institutional Turn in Political Philosophy' (2003) 29(4) Philosophy \& Social Criticism 375-406; in philosophy, ethics and business, see W. Dubbink, 'Institutions and the Institutional Turn in Business Ethics' in W. Dubbink, L. van Liedekerke and H van Luijk (eds.), European Business Ethics Cases in Context: The Morality of Corporate Decision Making (Springer, New York 2011) chapter 3.
} 
historical reality, namely the reality of the administrative state and its executive agencies that exercise regulatory power. Indeed, for Vermeule in particular, the increased resort to regulatory agencies and tribunals in the modern administrative state reflects a historical reality about the law that turns our attention from what a judge does or decides (i.e., the judicially-centered approach of the Common Law) to an institutional one in which regulators exercise various degrees of discretion pursuant to regulations drawn up by an executive acting pursuant to a legislative grant of authority. ${ }^{60}$ Certainly, as much as regulatory exercise of discretion concerns rule of law advocates, pragmatic concerns about governance reveal the need for some discretionary judgment. ${ }^{61}$ Moreover, this discretionary judgment begs important questions about the scope of judicial oversight or deference, and the standards of review courts can and should exercise when administrative decisions appear before them on appeal. ${ }^{62}$ Indeed, the edifice of the administrative state presents quite neatly an important site where debates on rule of law and legal interpretation take shape together in a particular, $20^{\text {th }}$ century development of the modern state.

Vermeule has masterfully reflected on the implications of varying capacities and expertise, as well as the economics of justice, to offer a "formalist" approach to legal interpretation as exercised by the judiciary. For Vermeule, judges should adopt a "consequentialist decision-making strategy". ${ }^{63}$ They should "decide cases, where possible, according to rules rather than standards, sticking close to the apparent or surface meaning of legal texts and placing great emphasis upon the value of legal certainty and the value of adhering to common understandings of constitutional and statutory commands." ${ }^{\circ 4}$ For Vermeule, such judicial interpretive restraint is appropriate because of the limited capacity of judges to review administrative decisions made by officials with (presumably) specialized knowledge of highly complex regulated areas of law.

Of particular interest for our purposes here, though, is not so much the merits of Vermeule's argument as much as his turn to particular institutional developments in the $20^{\text {th }}$ and $21^{\text {st }}$ century state so as to qualify the probity of abstract philosophies of the law. ${ }^{65}$ Indeed, Vermeule's theory is merely an interim theory of interpretation that awaits further empirical data on the state of a particular

60 A. Vermeule, Judging Under Uncertainty: An Institutional Theory of Legal Interpretation (Harvard University Press, Cambridge 2006).

${ }^{61} \mathrm{Raz}$ (n 30) 213, 215-216.

${ }^{62}$ A judicial example is Baker v Canada [1999] 2 SCR 817 (SCC) [Baker], discussed below. For more on the implications of Baker on administrative law questions, see D. Dyzenhaus (ed.), The Unity of Public Law (Hart Publishing, Portland, Oregon 2004).

${ }^{63}$ Vermeule (n 60) 72.

${ }^{64} \mathrm{ibid}$.

${ }^{65}$ Likewise, Kent Greenawalt asserts a model of statutory interpretation that reflects a concern with the historical in terms of his institutional and social values focus. He writes: "The best approach to statutory interpretation depends significantly on how institutions operate, and on social values, and on how both of these shift over time." K. Greenawalt, Statutory and Common Law Interpretation (Oxford University Press, New York 2013) 31. 
legal system. His theory is "a theory good only for an awkward transitional period in which academics and judges have begun to appreciate that the dispositive questions about the interpretive system are empirical and institutional rather than conceptual, but in which the relevant empirical information is largely absent."66

Notably, Vermeule's theory is a specifically American one, and as such may not be sufficiently reflective of the legal contours of other jurisdictions, as one reviewer has already suggested. ${ }^{67}$ But that is perhaps part of the power of his argument. The turn to the historical (in whatever guise), ultimately defines and delimits the terrain of a legal system. The significance of Vermeule to this analysis is therefore two-fold. First, his invocation of the institutional turn reveals how coupling the interpretive turn with a sensitivity to history, broadly construed, maps the rule of law (or in less grandiose terms, legality) as a bounded claim space. Second, his invocation (and critique) of the interpretive turn in law expressly reveals an approach to the rule of law through the analytic lens of legal interpretation. As Section $\mathrm{C}$ will show, conceptualizing rule of law as a "claim space" both raises fundamental questions about the inclusive and exclusive features of the boundaries that define that space, and sets the conditions of legality for a particular legal system.

\section{LEGAL INTERPRETATION AND THE TROPE OF BOUNDARIES: THE HISTORICAL AS PERIPHERY-SETTING}

The rule of law, as viewed through the lens of interpretation (and the fears of indeterminacy and subjective politics), forces us to account for the kinds of boundaries that limit the scope of interpretation without at the same time presuming that they dictate in determinate fashion a particular outcome. This section will show how competing approaches to legal interpretation invoke the trope of boundaries to characterize the enterprise of legal interpretation. The implication of this language about boundaries, when juxtaposed with the debates on rule of law, suggests that rule of law is better appreciated as a claim space within which arguments of justice are made. As a space, it is not infinite in its scope. It reflects a terrain of limited scope, and thus begs important questions about the boundaries that define and delimit that space. The boundaries to the rule of law claim space have a dual function. They not only help us understand what counts as law (i.e., the conditions of legality) but they also have an exclusionary effect: they tell us what does not count as law, at least in a particular legal system, and in that sense often play a protective role in furtherance of the various presumptions that inform and even justify the spatial imaginary of the rule of law claim space. ${ }^{68}$

\footnotetext{
${ }^{66}$ Vermeule (n 60) 289.

${ }^{67}$ Colin Farrelly, 'The Institutional Theory of Legal Interpretation [Review of Judging Under Uncertainty]' (2008) 58 University of Toronto Law Journal 217-232.

68 This protective feature of boundaries is perhaps most evident when minority groups appear before courts of law. For a sustained analysis of this protective dimension of the rule of law, see Emon, Religious Pluralism.
} 
Accounting for those boundaries both gives a thick content to the rule of law as an analytic concept, and limits the scope to which it can be applied across traditions or jurisdictions generally or abstractly.

The literature on law and interpretation is vast, and there is nothing new that this article will offer to that literature. Of interest here is how that literature reveals a trope about boundaries. As will be argued below, to use that trope to inform rule of law debates foregrounds the kind of historical content that rule of law theorists only gesture to, but which no rule of law account ought to ignore. Introducing the trope of boundaries to rule of law debates about (arbitrary) decision-making allows us to map a rule of law claim space within which claims of justice are made. As such, this article will suggest that as much as rule of law or legality tend to be pitched at high levels of abstraction with mere gestures to history, the incorporation of a more robust historical accounting of the conditions of legality (i.e., the rule of law claim space) gives content to this aspirational phrase while perhaps also limiting the sometimes universalist claims that can be made in its name or on its behalf.

In the Foreword to Reading Law, Judge Frank H. Easterbrook, chief judge of the seventh circuit U.S. Court of Appeals, recognized both the inevitability of interpretation in adjudication as well as its potential abuse by those with life tenure on the bench. There is no formula for interpretation that protects the interpreted text from the subjective standpoint of the interpreter. Rather, interpretation "is a human enterprise, which cannot be carried out algorithmically by an expert system on a computer. But discretion can be hedged in by rules...."69 The authors of Reading Law, U.S. Supreme Court Justice Antonin Scalia and legal lexicographer Bryan A. Garner made a case for their preferred interpretive approach, textualism, at a time when they feared the law has lost an important degree of predictability because of a vanished fidelity to the legal text. ${ }^{70}$ The object of their study "is to remove a facile excuse for judicial overreaching - the notion that words can have no definite meaning." 71 Whatever one may think of these authors' attitudes about scope and legal interpretation, words such as "hedged in" and "overreaching" invoke images of constraining devices that either keep people within the bounds or effectively prevent people from scrambling over or around them.

These images are not at all uncommon across a range of writings on the topic of interpretation in the law. For instance, in a seminal article on the topic, Yale Law professor Owen Fiss argued against what he considered a nihilist turn in interpretive theory that destabilizes any sense of determinacy in language and meaning, thus rendering adjudication a mere cover for a judge's willful act of legal

69 F.H. Easterbrooke, 'Foreword' in A. Scalia and B.A Garner, Reading Law: The Interpretation of Legal Texts (Thomson/West, St. Paul, Minnesota 2012) xxi-xxvi, xxiii (emphasis added).

70 A. Scalia and B.A. Garner, Reading Law: The Interpretation of Legal Texts (Thomson/West, St. Paul, Minnesota 2012) xxvii.

71 ibid 6 (emphasis added). 
creation pursuant to his or her own proclivities. ${ }^{72}$ Fiss does not ignore the role of the subjective in the interpretive process. Rather his commitment to objectivity in the law is less about some absolute standard and rather a threshold requirement for purposes of law and legal authority. As he said, "the question is whether any judicial interpretation can achieve the measure of objectivity required by the idea of law." 73 To support his position, Fiss introduced two subsidiary concepts, "disciplining rules" and "interpretive community". Disciplining rules are what "constrain the interpreter and constitute the standards by which the correctness of the interpretation is to be judged", whereas the interpretive community is meant to capture that group of people, which "recognizes these [disciplining] rules as authoritative". ${ }^{74}$

Of particular interest here is Fiss' discussion of disciplining rules and how they contribute to the trope of boundaries that seems present across a range of interpretive accounts of the law. He wrote:

Though the particular content of disciplining rules varies, their function is the same. They constrain the interpreter, thus transforming the interpretive process from a subjective to an objective one, and they furnish the standards by which the correctness of the interpretation can be judged. These rules are not simply standards or principles held by individual judges, but instead constitute the institution (the profession) in which judges find themselves and through which they $^{\text {act. }^{75}}$

For Fiss, disciplining rules constrain or limit interpretation, and thus gesture to an institutional space within which interpreters find themselves and from which they make conclusions of law. Indeed, the language of constraint and the spatial imagery around "institution" reveal a sense of a defined and delimited space, where the boundaries of that space give content to the conditions of legality. Indeed, Fiss went so far as to say "the disciplining rules that govern an interpretive activity must be seen as defining or demarcating an interpretive community consisting of those who recognize the rules as authoritative."76 Far from seeking

\footnotetext{
72 O. Fiss, 'Objectivity and Interpretation' (1982) 34 Stanford Law Review 739-763, 740-2. As an example of this kind of politically nihilist approach to language and meaning, John Willis critiques the "golden rule" of interpreting in light of a perceived absurdity: "[Absurdity] is infinitely more a matter of personal opinion and infinitely more susceptible to the influence of personal prejudice. The result is that in ultimate analysis, the 'golden rule' does allow a court to make quite openly exceptions which are based not on the social policy behind the Act, not even on the total effect of the words used by the legislature, but purely on the social and political views of the men who happen to be sitting on the case." J. Willis, 'Statute Interpretation in a Nutshell' (1938) 16(1) The Canadian Bar Review 1$27,13$.

${ }^{73}$ Fiss (n 72) 744.

${ }^{74}$ ibid.

75 ibid 745 (emphasis added).

${ }^{76}$ ibid (emphasis added).
} 
some "brooding omnipresence in the sky", ${ }^{77}$ Fiss suggested that the requisite objectivity must merely be sufficient to meet the threshold requirements for authority in the law.

In his response to Fiss, Stanley Fish took aim at the idea of disciplining rules and the assumptions that make disciplining rules possible or intelligible. He criticized Fiss' distinction between the reader and the text, and doubted that disciplining rules are external standards that condition how the two ought to interact. Fish argued that the presumed distinction between the text and the reader does not account for how both are already embedded in a context, how they are both constitutive elements of the field of interpretation called "law". Fish wrote:

Since readers are already and always thinking within the norms, standards, criteria of evidence, purposes and goals of a shared enterprise, the meanings available to them have been preselected by their professional training; they are thus never in the position of confronting a text that has not already been 'given' a meaning by the interested perceptions they have developed. More generally, whereas Fiss thinks that readers and texts are in need of constraints, I would say that they are structures of constraint, at once components of and agents in the larger structure of a field of practices, practices that are the content of whatever 'rules' one might identify as belonging to the enterprise. ${ }^{78}$

Moreover, " $[\mathrm{t}] \mathrm{o}$ be... 'deeply inside' a context is to be already and always thinking (and perceiving) with and within the norms, standards, definitions, routines, and understood goals that both define and are defined by that context."79

Despite their disagreement, both Fish and Fiss draw upon the imagery of boundaries to delineate the scope of interpretation possible within the field of law. Fiss, for instance, wrote: "Bounded objectivity is the only kind of objectivity to which the law...ever aspires and the only one about which we care." ${ }^{\text {" Likewise, }}$ Fish utilized similar boundary imagery to describe the limitations on discretion in the law. As much as he disagrees with the idea of independent disciplining rules, he adopted an almost spatial or physical sense (e.g., "structures", "field") of the legal interpreter's location (e.g., "deeply inside"), which is bounded by a set of constraining practices. ${ }^{81}$

While rule of law debates reflect deep concerns about discretion, they also tend to make broad gestures to context or history as a way to condition or limit the scope

77 ibid 756.

${ }^{78}$ S. Fish, 'Fish v. Fiss' (1984) 36(6) Stanford Law Review 325-1347, 1339 (underlining added).

79 ibid 1332.

${ }^{80}$ Fiss (n 72) 745 (emphasis added).

${ }^{81}$ See also, K. Greenawalt, Law and Objectivity (Oxford University Press, New York 1992) 193 , who writes about "[r] easoning within the law" to refer to "all reasoning that is relevant to reaching decisions about what the law provides". The preposition "within", when read alongside the language used by Fiss and Fish, connotes spatiality, and thus a zone that demarcates what is inside and outside the realm of law. 
of discretion that is possible. In parallel fashion, debates on interpretation and objectivity in the law also make reference to certain conditions that limit the indeterminacy in legal interpretation, and thus allow for a degree of determinacy that contributes to the legitimacy of a particular legal outcome. Juxtaposing both lines of scholarly inquiry reveals that the gestures to history however phrased (e.g., context, particularity, institutions, or even "disciplining rules") draw upon a shared trope, namely boundaries. Boundaries are interesting because they both keep together things that fall inside the space, and exclude those things that do not belong in that space. Moreover, they may be porous enough to permit limited movement back and forth. Boundaries also reflect the outer bounds or periphery so to speak, and thereby imply a center in which the existence of a periphery may be so taken for granted as to be unseen or unaccounted. Boundaries fundamentally speak to the spatial approach adopted herein that characterizes rule of law as a claim space within which claims of justice are made. By including and excluding, boundaries constitute and define the space being delimited.

\section{STATUTORY INTERPRETATION IN THE CANADIAN CONTEXT: MAPPING A RULE OF LAW CLAIM SPACE}

As suggested above, rule of law gestures to a certain history, whether expressed in terms of a sense of "fit" or a set of "social facts". Moreover, debates on legal interpretation seem to be concerned with disciplining, constraining, or hedging in the interpreter within a certain ambit of appropriate legal argument. Rule of law, when read with an attention to history and the limiting conditions of legal interpretation, is better appreciated as a claim space, which in turn implies the existence of boundaries that demarcate the distinctiveness of that space. This is not to suggest that to know such boundaries implies absolute determinacy in legal judgment. As much as the argument below reveals certain boundary conditions, there is considerable space for debate about the implications of such boundary conditions on legal determinations. As Kent Greenawalt has insightfully illustrated in his study of statutory and common law interpretation,

much in the conception of the role of courts depends on how one understands a system of governance. Those who conceive of liberal democracy as essentially majority rule, subject to limitations in favor of individual rights that are (commonly) protected by a constitution, are likely to regard the legislature as best representing the majority... If one regards the United States or any other particular system of government as not reducible to a qualified majoritarianism, one may see courts as protectors against unjust and unwise legislative decisions. ${ }^{82}$

For instance, as discussed below, one boundary of the Canadian rule of law claim space reflects a commitment to democracy. But what democracy means is a subject

${ }^{82}$ Greenawalt (n 65) 9. 
open to debate. As much as the historical content of rule of law can help map a claim space, the implications of any boundaries to that space remain open to a limited range of debate, as illustrated by Greenawalt's example. This indeterminacy in meaning or consequence is not fatal to the description of rule of law as a claim space. Rather it speaks to the analytic limits of "rule of law" as a concept. On the one hand, the limit may reveal a tendency toward an institutional formalism that marks the outer boundary of a claim space, thus leaving considerable room for debate about what might fall within a delimited claim space. On the other hand, the limit applies to the ability for one rule of law claim space to transcend its own history and be transplanted to another jurisdiction entirely. To imagine the idea of claim space visually, I offer the diagram below. The large circle represents a rule of law claim space for a given legal system. The small spheres that lie on the circle itself represent the ramparts that demarcate the boundaries of that claim space, and hedge inward (as well as preclude by excluding) the range of potential interpretations of the law. Whether contingent facts, ideas of procedural fairness or fit, or disciplining rules limit and hedge in the interpreter, the task before us is to address what those boundaries are and how best to appreciate their operation on the interpretation of the law.

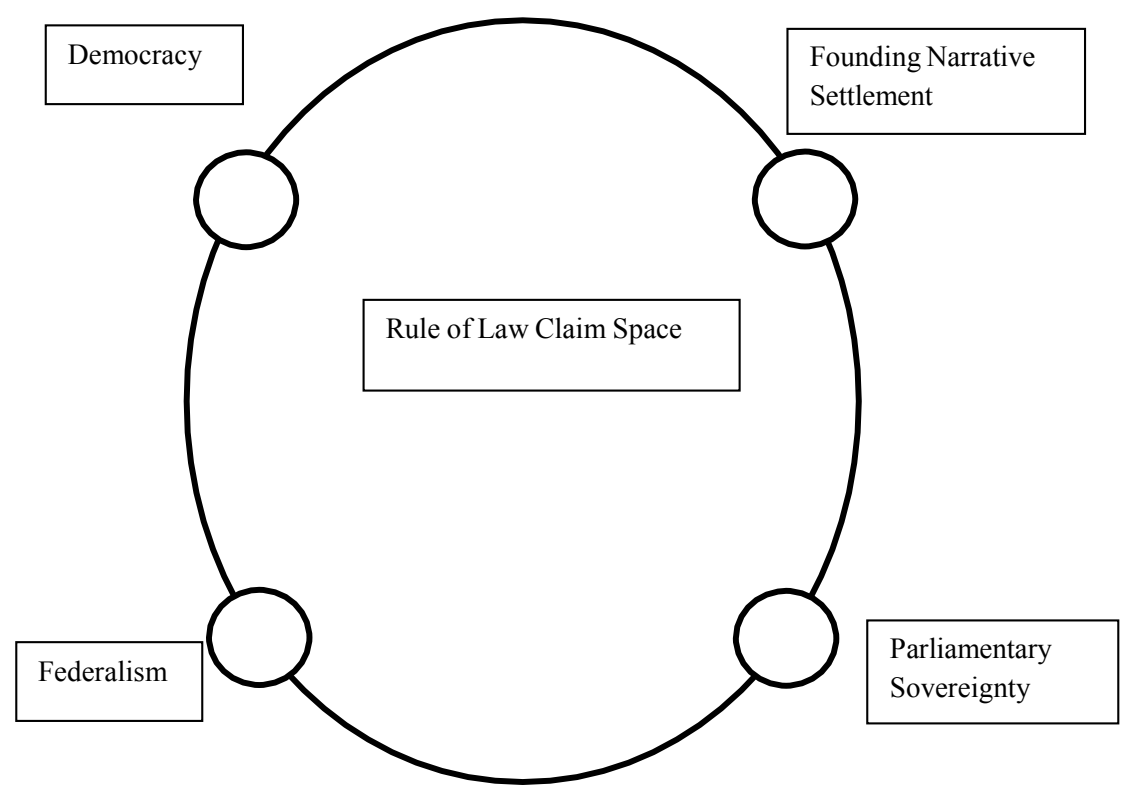


In this section, I propose to illustrate the operation of some boundary conditions in the Canadian rule of law claim space by reference to Canadian jurisprudence on statutory interpretation. I focus on Canada in order to situate the inquiry in a particular legal tradition, and as such draw upon its history to inform the content of the boundary conditions. Moreover, I will suggest that debates on rule of law or legality that are pitched at the level of abstract philosophical speculation may benefit from greater attention to the historical dimension of law. Indeed, without such historical attention, rule of law and legality debates will remain trapped in their current state of ambiguity - an ambiguity that has potentially damaging effects for those regions subject to rule of law development projects. ${ }^{83}$ The focus on statutory interpretation is particularly important because it offers an important vehicle for introducing the boundary conditions of a rule of law claim space. Boundaries lie at the periphery, and as such are often so assumed, or taken for granted, that they are often not duly accounted for despite their outright salience in legal determinations. Statutory interpretation, as a form of legal interpretation, cannot help but reflect those boundary conditions as justices of the court contest in their opinions about how best to hedge in their decisions amidst a range of possible legal outcomes.

\section{Ordinary Meaning \& Technical Meaning: The Boundary of Democratic Accountability}

Sullivan writes of the ordinary meaning presumption that "the ordinary meaning of a legislative text is the meaning intended by the legislature. In the absence of a reason to reject it, the ordinary meaning prevails." ${ }^{84}$ As interpretive presumptions go, the ordinary meaning presumption assumes a certain pride of place, a first among equals, in Canadian statutory interpretation, whose primacy draws upon the authority of Elmer Driedger's famous dictum about contextual interpretation and the grammatical and ordinary sense of legislation. ${ }^{85}$ Yet, as Sullivan noted, "ordinary meaning" is hardly ordinary and perhaps not particularly meaningful given the indeterminacy that often inheres in language. ${ }^{86}$ Nonetheless, for purposes of statutory interpretation, courts will presume that the "ordinary meaning of a legislative text is the meaning intended by the legislature. In the absence of a reason to reject it, the ordinary meaning prevails." 87 This of course begs a further question, namely what does "ordinary" mean? Again, Sullivan remarked that most often, "ordinary meaning refers to the reader's first impression meaning, the understanding that spontaneously comes to mind when words are

\footnotetext{
83 See generally, Humphreys (n 7).

84 Sullivan (n 13) 24.

85 ibid 26.

86 ibid 23.

87 ibid 24.
} 
read in their immediate context." 88 Sullivan carefully recognizes that what is ordinary is not always plain, and more often than not the ordinary meaning is evident when viewing the words in context, as Elmer Driedger would advise. ${ }^{89}$ Of particular interest here is why this presumption is the first to which a legislative interpreter would or ought to turn.

To answer, this question in large part turns on rule of law considerations about notice, namely who is presumed to read and be affected by legislation. Audience matters. The significance of audience is especially poignant where the presumption of ordinary meaning can be rebutted by the presence of a technical meaning. As Canadian courts have noted on numerous occasions, if a word can equally bear an "ordinary" or a "technical" meaning, the ambiguity is resolved in favour of the ordinary meaning. ${ }^{90}$ The reason for this has to do with democratic accountability to an electorate, and its implications for how the legislature is presumed to draft legislation. To defeat the presumption of ordinary meaning, one must identify the relevant audience for the statute. Consequently, interpretive presumptions about ordinary and technical meaning operate as proxies for the boundary of representative democracy and what it implies about the reader(s) and the author of legislation.

Why start with ordinary meaning? Writing in 1977, Justice Pigeon remarked that " $[\mathrm{t}]$ he rule that statutes are to be construed according to the meaning of the words in common language is quite firmly established and it is applicable to statutes dealing with technical or scientific matters."91 Sullivan disagreed with Pigeon J.'s position, and advocated a more nuanced approach, one that ascribes a meaning to words based on the intended audience. ${ }^{92}$

There are important democratic reasons for giving preference to ordinary meaning, as illustrated in the debate between the majority and dissenting opinions in Will-Kare Paving. ${ }^{93}$ Will-Kare involved an income tax rebate provided in the Income Tax Act. In this case, justices of the Supreme Court of Canada had to construe the meaning of statutory terms that could have either a legal technical meaning or a more general, ordinary meaning.

Will-Kare was a paving company that built its own asphalt plant, with the purpose of expanding its paving operation and avoiding cost fluctuations in the asphalt market. The capital investment increased revenue in two ways, first by expanding the range of paving contracts it could undertake, and by providing an additional revenue stream from the sale of any excess asphalt it did not use in its paving service operations. For the taxation years at issue, Will-Kare utilized $75 \%$ of its asphalt in its paving contracts and sold the remaining $25 \%$ to third parties. For tax purposes, Will-Kare classified its capital investment in such a way as to

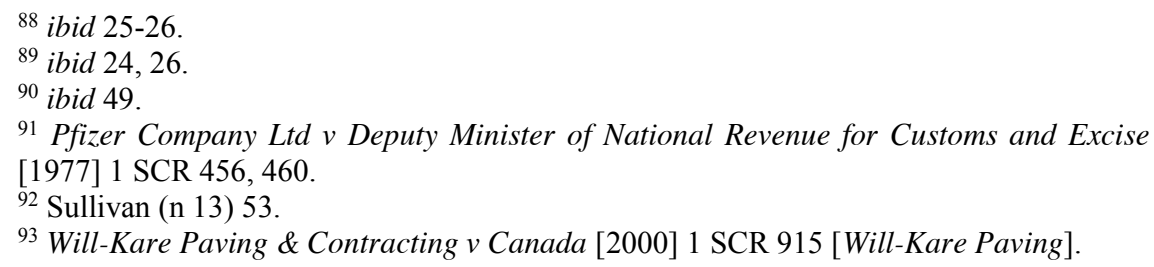


claim certain tax credits and cost allowances. It could do so, it argued, because "the plant was property used primarily in the manufacturing and processing of goods for sale." 94 When the Minister of National Revenue reassessed Will-Kare, it reclassified the asphalt plant. The government held that the asphalt plant was not used primarily for the manufacture of goods for sale, but rather for the manufacture of goods that Will-Kare used in performance of its service contracts. The reclassification precluded Will-Kare from benefiting from certain tax credits and capital cost allowances.

The relevant statutory language concerned s. 127(9) of the Income Tax Act. Of particular

"qualified property," of a taxpayer, means property...that is

(c) to be used by the taxpayer in Canada primarily for the purpose of...

(i) manufacturing or processing goods for sale or lease. ${ }^{95}$

According to the Minister, Will-Kare's plant was not used primarily for the purpose of manufacturing goods for sale or lease since $75 \%$ of the asphalt it produced was used for its own service contracts, and not in fact put on the market for sale. The question for the Supreme Court of Canada was how to construe the terms "sale" and "lease" in the statute. On the one hand, on an ordinary meaning approach the contracts of service (which implied the use of the asphalt) were sufficiently akin to a sale, and thus the plant should qualify under this section. On the other hand, "sale" and "lease" are technical legal terms of art drawn from the Common Law; in their technical sense, both terms are distinct from "service", and thus the use of asphalt in Will-Kare's service contracts does not fall within the scope of a technical construal of "sale".

Writing for the majority, Major J. found against Will-Kare. He outlined the above two approaches to construing the meaning of terms like "sale" and "lease". ${ }^{96}$ Finding the legislative history of this statutory provision less than dispositive, Major J. declared that "sale" and "lease" have established legal meanings, and that Parliament must have known what these meanings were when it drafted the legislation to read as it does. Major J. remarked,

[I]t remains that in drafting the manufacturing processing initiatives to include reference to sale or lease, Parliament has chosen to use language that imports relatively fine private law distinctions. Indeed, the Act is replete with such distinctions. Absent express direction that an interpretation other than ascribed by settled commercial law be applied, it would be inappropriate to do so. ${ }^{97}$

\footnotetext{
94 ibid 922.

${ }^{95}$ Income Tax Act, RSC 1985, c 1 (5 $5^{\text {th }}$ Supp), s. 127(9).

${ }^{96}$ Will-Kare Paving (n 93) 930.

${ }^{97}$ ibid 933.
} 
It is hard to avoid noticing that Major J. turned the presumption of ordinary meaning on its head. He characterized the Act as fundamentally technical; consequently, he required express direction to read the language in the Act in an ordinary manner.

In his dissenting opinion, Binnie J. objected to the technical reading given to the terms "sale" and "lease". His reasons had everything to do with how one construes the audience for whom Parliament drafts legislation. For Binnie J., if the audience is construed as the self-assessing taxpayer, the court must be careful when ascribing technical meanings to words. Otherwise, to do so may require too much prior knowledge of the relevant audience. As Binnie J. remarked, "[t]he millions of taxpayers who are not lawyers cannot be expected to reach for Benjamin's Sale of Goods to research the difference between a contract for the sale of goods and a contract for work and materials and to apply these distinctions in the assessment of their own income tax liability." 98

As far as Binnie J. was concerned, the percentage of the asphalt used in the service contracts as opposed to the contracts for sale did not matter. All the asphalt was subject to sale, given "the ordinary meaning of the word in everyday speech." 99 Moreover, Binnie J. suggested a different way to construe the production of the asphalt and its use in the service contracts. He argued that immediately upon its manufacture, the asphalt was presumably ready for sale. Only thereafter was much of it directed through service contracts. On this understanding of the facts, Binnie J. argued that a technical reading of the legislation would actually read into the statute language that Parliament did not include, namely "goods to be disposed of under contracts for sale or lease." 100 And lastly, Binnie J. pointed out the uncontested irony, if not absurdity, that "if the taxpayer had sold to its paving customers the asphalt in one contract and the installation of it in another, it would be entitled to the deduction." 101 In other words, not only did the technical reading present an absurd outcome, it required reading into the statute language that Parliament did not enact.

Ultimately animating Binnie J.'s concern was how a technical reading of terms like "sale" or "lease" will confound the "self-assessing taxpayer". Indeed, by construing the self-assessing taxpayer as the principal audience, and thereby presuming the need for a "plain" reading of the language, Binnie J. worked backward to construe what Parliament could have done to make its meaning clear if it indeed wanted to exclude goods included in service contracts:

I do not think it unreasonable to require the legislative drafter to make it plain (if such be the intent) that the product must not only be manufactured for sale, but must be disposed of under a specific type of contract, e.g., excluding

\footnotetext{
98 ibid 936.

${ }^{99}$ ibid 939, citing La Forest J. in H.W. Liebig \& Co. v Leading Investments Ltd. [1986] 1 SCR 70, 83-84.

${ }^{100}$ Will-Kare Paving (n 93) 937.

101 ibid 937.
} 
contracts for work and materials. It would be a simple matter to signal the taxpayer in ordinary language that if he or she supplies services along with the manufactured product... the investment tax credit will be forfeited. ${ }^{102}$

Binnie J.'s ordinary, self-assessing taxpayer is not necessarily a lawyer and cannot be expected to reach for specialized treatises or manuals to learn what "sale" or "lease" mean. The self-assessing taxpayer is no one other than all of us who pay taxes, and as such operates as a trope not only for legislative audience, but more profoundly, for certain representative democratic commitments of notice and accountability. As much as Binnie J. employed various techniques of statutory interpretation - plain meaning, technical meaning, legislative history, and intent at the end of his dissent, he once again turned to the self-assessing taxpayer as the principal audience who sets the standard for evaluating how to construe the statute's language. In a particularly revealing sentence, he concluded his dissent as follows: "While there is little danger that the Act will ever become user-friendly or self-explanatory, it is of particular importance in a self-assessment tax system to promote an interpretation of provisions, where possible, that is comprehensible to the taxpayers themselves." 103

If the ordinary meaning presumption is animated in part by certain democratic commitments, technical meaning can potentially threaten democratic accountability. As Lisa Philipps has argued, "technical discourses can...have a profoundly undemocratic and socially regressive effect." 104 One way to argue for a technical meaning without running afoul of certain democratic commitments of accessibility, accountability, and notice is to construe the audience for a particular piece of legislation (or section thereof) as narrow and specialized. This requires a close reading of the statute for textual indications from which to infer either a narrow or broad audience. Moreover, with complex legislation that targets a range of potential audiences - large and small, general and specialized - one would first need to identify the intended audience of a provision, set of provisions, or an Act.

The need to identify the audience as a condition for defeating the ordinary meaning presumption and asserting a technical meaning is illustrated by the Federal Court decision in Double N Earth Movers Ltd. v Canada. ${ }^{105}$ At issue in the case was a tax rebate for fuel used in mining-related activities, as provided for in s. 69 of the Excise Tax Act. Under s. 69(6), a purchaser or importer of fuel can claim a rebate if the fuel has been used in mining. According to s. 69(1) of that Act, mining includes among other things, "the restoration of strip-mined land to a usable condition." ${ }^{106}$ In this case, the party claiming the rebate, Double N, restored

\footnotetext{
102 ibid 944-5.

103 ibid 948-9.

${ }^{104}$ L. Philipps, 'Discursive Deficits: A Feminist Perspective on the Power of Technical Knowledge in Fiscal Law and Policy' (1996) 11 Canadian Journal of Law \& Society 141176, 149.

${ }^{105}$ Double N Earth Movers Ltd v Canada [1998] CanLII 8125 (FC); 148 FTR 312 [Double $N]$.

${ }^{106}$ Excise Tax Act, RSC 1985, c E-15.
} 
strip-mined land using heavy machinery powered by fuel, for which Double $\mathrm{N}$ sought a rebate. The question at issue was what "restoration" meant and the kinds of activities it included. Without getting into the technical details of the restoration process, Double $\mathrm{N}$ used a variety of processes to restore strip-mined land. In some instances, it removed different layers of earth and stockpiled them in a storage site for later use. In other instances, it took that stockpiled layer of earth and used it to restore strip-mined areas. While Double $\mathrm{N}$ was certainly engaged in a miningrelated activity, the question was whether all of its activities qualified as "restoration". The Minister reviewing Double N's claim for the rebate found that the fuel used for purposes of stockpiling did not fall within the meaning of "restoration" but the fuel used for purposes of applying the stockpiled material on strip-mined land did count as "restoration".

At issue in Double $N$ was whether the word "restoration" should be read in its ordinary or technical sense. Counsel for the Minister, which argued for the ordinary meaning of the terms, held that removing and storing different layers of earth do not fall within an ordinary construal of the word "restoration". Double N, however, argued that within the mining industry, restoration involves all of its activities, and is so understood by those familiar with the trade.

The court considered whether or not the presumption of ordinary meaning was rebutted or not. Outlining various principles of interpretation pertaining to ordinary and technical meaning, the court noted that where "words are ambiguous in the sense that they could bear either a technical or non-technical meaning in the context in which they appear, the courts presume that the ordinary, non-technical meaning was intended." 107 However, as presumptions go, they can be rebutted. To rebut the presumption here required audience analysis. The Double $N$ court stated: "the primary objective is to determine the audience that is being addressed in a particular piece of legislation. If it is addressed to a trade audience, members of the trade audience are the persons who should be consulted on the meaning to be given to specific terms in the legislation." 108

After reviewing the parties' arguments and examining expert evidence on the usage of terms like "restoration" in the mining industry, the court found that s. 69 of the Excise Tax Act was "clearly passed with reference to trade conducted within particular segments of the resource industrial sector of the Canadian economy."109 Moreover, the very terms of the section presume a certain specialized knowledge that only a segment of the Canadian population would know. Consequently, given that the section affects a "select and limited group of economic entities" and given the "frequent use of technical trade terms throughout the section", the court held that the terms of the section should be read in light of how those in the relevant industries would understand them. ${ }^{110}$

\footnotetext{
${ }^{107}$ Double N (n 105) 17.

108 ibid 19.

109 ibid 32.

110 ibid 34-35.
} 
Construing the audience of a section is certainly not an easy matter. The difficulty is compounded when the legislation under consideration is complex and designed for a wide range of end-readers, sophisticated and unsophisticated. This is particularly so in the case of statutes such as the Income Tax Act, whose enforcement is often framed by competing attitudes toward taxpayer liberty and a general anti-avoidance rule designed to enhance the efficiency of the taxation regime. The general anti-avoidance rule (GAAR) of the Income Tax Act states: "Where a transaction is an avoidance transaction, the tax consequences to a person shall be determined as is reasonable in the circumstances in order to deny a tax benefit that, but for this section, would result, directly or indirectly from that transaction or from a series of transactions that includes that transaction."111 The use of the passive tense in the italicized section presents a challenge to the courts to determine the role they will play in applying provisions of the Act to particular transactions. As Lisa Philipps has argued, "the GAAR directly confronts the issue of judicial role. It calls for a new working relationship between legislative and judicial branches to repair the tax system's chronic vulnerability to the creative manoeuvres of tax planners." 112 But as Sullivan and others have shown, the courts have not entered the robust analytic space that the GAAR has opened. ${ }^{113}$

As the above analysis suggests, even as many hope the courts might play a robust role in the tax law arena, the courts are beset by a fundamental dilemma when interpreting statutes like the Income Tax Act. As Philipps has noted, "[t]axation has profound political implications for all citizens because of its effects on the distribution of income and wealth among individuals and social classes. Tax policy development, however, has been captured to a large degree by specialists." "114 The more one imagines the readers of the tax code to be specialists, the more one can insist that the courts take an increasingly active role in construing tax legislation in light of technical, complex tax law and policy debates. As such, it is not surprising that elsewhere Philipps described the end-users of the tax code to be primarily "tax lawyers and accountants", ${ }^{115}$ "transnational corporations... [and the] wealthiest taxpayers". ${ }^{116}$ Indeed, she has gone so far as to suggest ([pace] Binnie J.), "the simplistic image of the taxpayer in need of protection from an overwhelmingly greater state power is no longer realistic." 117

Alternatively, the more one emphasizes the universal application of such fiscal legislation on all Canadians, the more one will emphasize a restrained judicial approach, one that may focus on determinacy, predictability, and ordinary meaning, given certain traditional attitudes about private protection from

\footnotetext{
${ }^{111}$ Income Tax Act, RSC 1985, c 1 (5 $5^{\text {th }}$ Supp), s. 245(2) (emphasis added).

${ }^{112}$ L. Philipps, 'The Supreme Court of Canada's Tax Jurisprudence: What's Wrong with the Rule of Law' (2000) 79 The Canadian Bar Review 120-144, 122.

113 Sullivan (n 13) 527-536.

114 Philipps (n 104) 152.

${ }^{115}$ Philipps (n 112) 127.

116 ibid 130.

117 ibid.
} 
government over-reach. ${ }^{118}$ Perhaps the challenge underlying both of these approaches is their implicit reliance on a false dichotomy between the sophisticated tax specialist and the self-assessing taxpayer.

Stepping back from the ideologies informing this dichotomy, we encounter the reality of the modern, social, democratic administrative Canadian state and the increasing complexity of modern legislation. We can also recognize that despite the simple trope of democratic accountability, democratic accessibility is in fact a mediated concept involving representatives of government, administrative agencies, and other service agencies that bridge the gap between the need for increasingly complex programmatic legislation and what the average Canadian can understand. From this institutional-cum-historical awareness of the nature of legislation in the modern Canadian state follows certain implications for interpretation and drafting.

Complex legislation can no longer be presumed to have a single audience; rather, such legislation has multiple audiences. The onus on the court (as well as legislative drafters) is to identify when certain sections speak to a broad audience and when others speak to a narrow audience. As such, the majority and dissenting opinions in Will-Kare needed to do more than simply speak to the technical meaning of "sale" and "lease" or concerns about the self-assessing taxpayer. Instead, both ought to have explored the section in which those words occurred, and who the presumed audience of that section might be as was done by the court in Double N. This sort of inquiry balances the need to devise complex legislation in the modern state and to satisfy certain democratic commitments concerning notice, accountability, and accessibility.

\section{International Law in Domestic Courts: The Boundary of Parliamentary Sovereignty}

To invoke international law in a discussion of the rule of law claim space immediately highlights the exclusionary function of the boundaries of a sovereign state's rule of law claim space. From the perspective of statutory interpretation, international law presents the question of whether and to what extent courts can interpret domestic statutes in light of international law. From the point of legal practice, this is of course an important question, if not the most immediate question that faces an interpreter. But for this article, the practical question raises another, more fundamental one: what are the reasons why international law may be excluded from such interpretive consideration? Furthermore, what do those

\footnotetext{
${ }^{118}$ In this vein, the Uniform Law Conference of Canada's drafting conventions stipulate, "An Act should be written simply, clearly and concisely, with the required degree of precision, and as much as possible in ordinary language. Simplicity and conciseness of language can be made to exist with precision in a well-organized text. It is important not to exaggerate the degree of precision that is required." Uniform Law Conference of Canada Drafting Conventions, available at $<$ http://www.ulcc.ca/en/uniform-acts-en-gb-1/546drafting-conventions/66-drafting-conventions-act> accessed 15 February 2014.
} 
reasons (whether exclusionary or inclusive) reveal about a Canadian rule of law claim space?

Baker $v$ Canada is particularly instructive in this regard. The case concerned a mother who overstayed her visa, was not legally a resident in Canada, and who sought permanent residency. ${ }^{19}$ Under the Immigration Act, she had to apply for permanent residency outside of Canada. She was unwilling to leave Canada because she had two dependent children, both born in Canada and thus Canadian citizens, who would suffer greatly if she were required to leave the country. Immigration regulations allowed for some exceptions to the application requirement, in particular for humanitarian and compassionate reasons. The question for the Supreme Court of Canada was what "humanitarian and compassionate" meant, and in particular whether it should account for the effect of the application requirement on the welfare of Ms. Baker's children. Baker $v$ Canada was a significant decision in the field of administrative law. ${ }^{120}$ Indeed, the lawyer for Ms. Baker at the Supreme Court of Canada has called the decision "a landmark decision in Canadian administrative law." 121

As much as this case is heralded as a landmark administrative law case with implications for international law in domestic court settings, ${ }^{122}$ at its heart, it is a case of statutory interpretation. From that disciplinary perspective, this section will examine the court's reasoning about whether and to what extent international law can be used to interpret domestic legislation. At issue was how to determine the meaning of a key phrase that appeared in both the statute and regulations at issue in this case, namely "compassionate or humanitarian considerations". Specifically at issue was whether such considerations must include (if not prioritize) the best interests of Ms. Baker's children given Canada's ratification (but not legislative implementation) of the Convention on the Rights of the Child.

In her opinion for the majority, L'Heureux-Dubé J. held that "a reasonable exercise of the power conferred by the section requires close attention to the interests and needs of children. Children's rights, and attention to their interests, are central humanitarian and compassionate values in Canadian society." 123 An examination of the structure of her justification reveals a fascinating set of

\footnotetext{
119 For a comment on the case, see E. Adjin-Tettey, 'Case Comment: Baker v. Canada (Minister of Citizenship and Immigration)' (2000) 12 Canadian Journal of Women and the Law 454-463.

${ }^{120}$ D. Dyzenhaus and E. Fox-Decent, 'Rethinking the Process/Substance Distinction: Baker v. Canada' (2001) 51(3) The University of Toronto Law Journal 193-242.

121 R. Rowe, 'Baker Revisited 2007' (2008) 38(3) Journal of Black Studies 338-345. Incidentally, an entire book has been devoted to Baker's contribution to the scope of judicial review of administrative tribunal decisions and the requirement of procedural fairness. Dyzenhaus (n 62).

${ }^{122}$ On the implications of international law in domestic court settings, see K. Knop, 'Here and There: International Law in Domestic Courts' (1999-2000) 32 New York University Journal of International Law and Policy 501-535.

${ }^{123}$ Baker (n 62) 860.
} 
interpretive moves that raise fundamental questions about the bordering function of the rule of law.

L'Heureux-Dubé J. began by examining the Immigration Act's objectives, specifically reuniting citizens and permanent residents in Canada with their close relatives in other countries. Narrowly read, that objective did not apply to Ms. Baker. Her children were citizens; she was not, and moreover she was residing (illegally) in Canada. A narrow construction of that passage, therefore, would seem inapposite to the case at hand. But L'Heureux-Dubé J. applied a "large and liberal interpretation" of this provision to presume that Parliament "placed a high value on keeping citizens and permanent residents together with their close relatives who are already in Canada." 124

She then turned to international law, and specifically referred to "the ratification by Canada of the Convention on the Rights of the Child, and the recognition of the importance of children's rights and the best interests of children in other international instruments ratified by Canada." 125 Importantly, L'HeureuxDubé J. made no reference to the "other international instruments" ratified by Canada at this point in the opinion, though later she referenced the Universal Declaration of Human Rights and the United Nation's Declaration of the Rights of the Child. As Mayo Moran has argued, the reference to the Convention occupies a central and significant role in the analysis: "Not only are the Act and the guidelines discussed far more briefly than international law, but neither of those sources makes explicit reference to the importance of giving special weight to the interests of children." ${ }^{126}$ In fact, analyzed structurally, L'Heureux-Dubé J.'s opinion curiously examined international law before the domestic ministerial guidelines that advise regulatory officials in their decision-making process.

This mere gesture to other international instruments without more is also curious. If she had referenced a range of international instruments, she might have argued inductively for an international customary norm. She thereby could have argued that there is a presumption of compliance with such norms, both as a matter of domestic legislation and the Common Law, and thereby read this norm into the relevant statute. On such a reading, she could have made use of two principles of statutory interpretation, namely the presumptive compliance with international law and the presumptive compliance with the Common Law. ${ }^{127}$ But without referencing any other treaty except the Convention on the Rights of the Child, she gave the appearance of making a deductive argument about the meaning of the provision in the Immigration Act by reference to an international treaty that had been ratified but not yet implemented into domestic Canadian law. Arguably, this appearance of deductive reasoning posed (and still does) serious concerns about

\footnotetext{
124 ibid 860 .

125 ibid 860-61.

${ }^{126}$ M. Moran, 'Authority, Influence and Persuasion: Baker, Charter Values and the Puzzle of Method' in D. Dyzenhaus (ed.), The Unity of Public Law (Hart Publishing, Portland, Oregon 2004) 389-429, 395.

127 Sullivan (n 13) 537.
} 
the boundaries of Canada's rule of law claim space, in particular with reference to the boundary function of parliamentary sovereignty.

L'Heureux-Dubé J. was fully aware that unimplemented treaties "have no direct application within Canadian law." 128 Indeed, this was the basic point of the concurrence, in which Iacobucci and Cory JJ. agreed with the disposition of the case, but disagreed with the reference to international law. They argued that "an international convention ratified by the executive branch of government is of no force or effect within the Canadian legal system until such time as its provisions have been incorporated into domestic law by way of implementing legislation."129 For Iacobucci and Cory JJ., the overwhelming reason for writing separately had everything to do with preserving "the balance maintained by our Parliamentary tradition." 130 That tradition demands cognizance of parliamentary sovereignty, democratic accountability, and the implications of both on the separation of powers between the government and the legislature in a parliamentary system in which the two overlap institutionally. They feared that the result of the majority decision was "to give force and effect within the domestic legal system to international obligations undertaken by the executive alone that have yet to be subject to the democratic will of Parliament." 131

L'Heureux-Dubé J.'s principal response to her colleagues was to make a distinction between international law generally, and international human rights law more narrowly. She stated: "the values reflected in international human rights law may help inform the contextual approach to statutory interpretation and judicial review." 132

The distinction between ratification and implementation puts into stark relief a concern about parliamentary sovereignty, which constitutes a boundary device that helps determine whether foreign or international law can be admitted into the Canadian rule of law claim space, or rather must be excluded. The Baker majority arguably ran afoul of the significance of parliamentary sovereignty as a restraining device. This concern is especially prescient in a parliamentary context in which the ministers of government not only sit as members of parliament, but have increasingly since the $20^{\text {th }}$ century assumed greater roles and responsibilities in devising legislation in furtherance of the government's legislative agenda. In his recent study of legislation in the United Kingdom, Neil Duxbury has drawn attention to this phenomenon in the context of the British Parliament:

During the twentieth century, not only did the putting into effect of primary legislation increasingly become the task of the executive, but the executive was becoming ever more responsible for proposing primary legislation itself and indeed - because the government controls both the voting of the majority of

\footnotetext{
${ }^{128}$ Baker (n 62) 861.

129 ibid 865.

130 ibid.

131 ibid 866.

132 ibid 861
} 
the commons and, to a considerable extent, the legislative programme for a parliamentary session - for determining which legislative proposals were most likely to be enacted. ${ }^{133}$

For Duxbury, this development in legislative process raises serious challenges to the democratic logic underlying a separation of powers, and thus emphasizes the importance of parliamentary sovereignty as a bulwark against democratic deficiencies of an institutional and representative nature. ${ }^{134}$ Indeed, its importance is better appreciated when we compare the Canadian parliamentary system with the American presidential one. In the latter, foreign affairs powers (including treaty ratification) rest with the executive, though the Senate must confirm any treaty prior to it becoming domestic law. This distinction in institutional design presents a contextual factor that gives certain heft to the concurrence's critique of the majority in Baker.

This historical development (and distinction) in legislative design puts into stark relief the distinction in Baker between ratification and implementation, and the implication of that distinction on the very idea of parliamentary sovereignty. To argue in near deductive fashion from a ratified (but unimplemented) treaty to the meaning of a domestic statutory provision is effectively to perform an end-run around the sovereignty of the legislative function, and the democratic protections it is meant to afford.

In her treatise on the Construction of Statutes, Sullivan adopts a rather permissive attitude toward invoking international law as contextual fodder for interpretive purposes. Invoking anecdotal knowledge of federal legislative drafting practices, she writes that "in practice, at least at the federal level, before being enacted or made[,] all legislation is scrutinized by the Department of Justice to ensure compliance with international law...Apart from legislative intent, since Canada... is a participant in the international community and supports international rule of law, it is appropriate to read domestic legislation in light of international law." 135

Whether from L'Heureux-Dubé J. or Sullivan, this permissive attitude toward international law (or more narrowly international human rights law) does not adequately address the boundary function of parliamentary sovereignty - or its corollaries of separation of powers and democratic accountability - in defining a distinctively Canadian rule of law claim space. As much as the concurrence by Iacobucci and Cory JJ. may draw on what might be called an institutional formalism, such an uncharitable view ignores the underlying democratic

${ }^{133}$ N. Duxbury, Elements of Legislation (Cambridge University Press, Cambridge 2013) 41.

134 This potential threat of institutional blending, according to Duxbury, requires a more robust view of courts as protectors of individual liberty. Duxbury's position, though, is embedded in a larger debate in the UK that has occurred since 2009, when the legal role of the House of Lords was invested in a new Supreme Court, and thereby raised important questions about the nature and scope of judicial review.

${ }^{135}$ Sullivan (n 13) 548. 
commitments - which take different forms, institutional and otherwise - that animate and give shape to the Canadian rule of law claim space.

To conclude the analysis on Baker and international law, one question remains: namely why the majority limited its analysis to international human rights law, as opposed to other genres of international law. Certainly, some have urged caution against reading too much into Baker's apparent embrace of international human rights law as persuasive for purposes of informing context. ${ }^{136}$ Nonetheless, is there something distinctive about this area of international law that renders porous the parapets of parliamentary sovereignty? Does it matter that this case occurred after 1982, when the Charter of Rights and Freedoms was implemented into the Canadian constitution? Perhaps, as Moran has argued, the majority in Baker wanted to create a third approach to international law that pierced the binding/nonbinding dichotomy of international law, and thereby rendered the boundary permeable. ${ }^{137}$ Nothing about boundaries necessitates that they are hard, fast, or unrelenting. Indeed, the significance of a boundary is not merely that it both includes and excludes; a boundary holds out the possibility of admission (as well as removal, as Ms. Baker knew all too well). As much as the interpretive principle about international law offers a set of presumptions that speak to the inclusive and exclusionary function of boundaries, that such presumptions can be defeated begs questions (left unanswered in Baker) as to when such presumptions can and even should yield.

\section{Aboriginal Peoples and Legislation: The Boundary of Founding Narratives of Settlement and Confederacy}

If statutory interpretation reveals the boundaries of a rule of law claim space, and those boundaries reflect a certain history, then it follows that one jurisdiction's conception of rule of law is not easily transportable to other jurisdictions. In the Canadian context, history delineates the boundaries of a rule of law claim space when legislation that affects Canada's Aboriginal peoples must be interpreted. As Sullivan stated outright, "[i]t is well established that legislation relating to Aboriginal peoples should receive a large, liberal and purposive interpretation; doubts or ambiguities should be resolved in their favour." 138 The question that this presumption raises, though, is why adopt this particular reading? On its face, the reason seems obvious - the Aboriginal peoples of Canada were displaced by British and French settlers in the early history of Canada's founding; were subjected to violence, discrimination, and dispossession; and were denied the continuity of their traditions, language, and culture through the residential schools program. This history informs the nature of legal interpretation and the operation

\footnotetext{
136 J. Brunée and S.J. Toope, 'A Hesitant Embrace: Baker and the Application of International Law by Canadian Courts' in D. Dyzenhaus (ed.), The Unity of Public Law (Hart Publishing, Portland, Oregon 2004) 356-388, 358-9.

${ }^{137}$ Moran (n 126) 396-400.

138 Sullivan (n 13) 509.
} 
of certain presumptions of liberality. As such, the presumption of liberal interpretation concerning Aboriginal peoples reveals how Canadian history not only delineates Canada's rule of law claim space, but also limits the scope to which its rule of law system is transferrable to other jurisdictions.

In Nowegijick $v$ R., the Supreme Court of Canada gave distinctive expression to the presumption of liberal interpretation when Aboriginal peoples fall under legislative purview. ${ }^{139} \mathrm{Mr}$. Nowegijick was an "Indian" under the Indian Act, and was an employee of the Gull Bay Development Corporation in the 1975 tax year. Mr. Nowegijick worked and lived on the Gull Bay Reserve, where the corporation had its offices. Mr. Nowegijick worked for the corporation's logging operation, which was located ten miles away from the reserve; however, he picked up his wage checks from the corporate headquarters on the reserve, and resided on the reserve during this period. He objected to the tax assessment on his personal income for this year by reference to s. 87 of the Indian Act, which the Court stripped to its essentials to read as follows:

Notwithstanding any other Act of the Parliament of Canada...the following property is exempt from taxation, namely:

(a) the interest of an Indian or a band in reserve or surrendered lands; and

(b) the personal property of an Indian or band situated on a reserve; and no Indian or band is subject to taxation in respect of the ownership, occupation, possession or use of any property mentioned in paragraph (a) or (b) or is otherwise subject to taxation in respect of any such property. ${ }^{140}$

In his opinion for the court, Dickson J. made two remarks that sit uneasily together. When construing the meaning of s. 87 of the Indian Act, and particularly with respect to tax provisions, he remarked:

It is legal lore that, to be valid, exemptions to tax laws should be clearly expressed. It seems to me, however, that treaties and statutes related to Indians should be liberally construed and doubtful expressions resolved in favour of the Indians. If the statute contains language which can reasonably be construed to confer tax exemption that construction, in my view, is to be favoured over a more technical construction which might be available to deny exemption. ${ }^{141}$

Later in his opinion, again when construing the meaning of s. 87, he invoked the ordinary meaning presumption (and argued against adopting a technical meaning), when he stated:

\footnotetext{
${ }^{139}$ Nowegijick $v$ R. [1983] 1 SCR 29 [Nowegijick].

${ }^{140}$ ibid 33 (emphasis in original). For the Act itself, see Indian Act, RSC 1985, c I-5, s. 87.

${ }^{141}$ Nowegijick (n 139) 36.
} 
We must, I think, in these cases, have regard to substance and the plain and ordinary meaning of the language used, rather than to forensic dialectics. I do not think we should give any refined construction to the section. A person exempt from taxation in respect of any of his personal property would have difficulty in understanding why he should pay tax in respect of his wages. And I do not think it is a sufficient answer to say that the conception of the Income Tax Act renders it so. ${ }^{142}$

On the one hand, these two passages taken together support Mr. Nowegijick's claim against tax liability, especially given the reference to a liberal and broad reading of s. 87 . On the other hand, from a statutory interpretation perspective, the second passage adopts the ordinary meaning approach and avoids a technical reading, which might introduce certain democratic deficits. But the first passage espouses a broad and liberal reading, which is not necessarily an ordinary reading, and thereby puts the two passages in some tension with each other.

As much as Nowegijick is certainly cited for the proposition of a large and liberal reading of legislation affecting Aboriginal peoples, it also opens the door to fundamental questions about the meaning and scope of this presumption's application, and the priority to be given to such broad and liberal readings, as opposed to other readings. Is it a presumption applied to all legislation or just that bundle of legislation that applies to Aboriginal peoples? Is it a principle of first resort or last resort, to be used at the outset of an analysis or only where an ambiguity exists? And ultimately, what are the means by which the implications of the principle's liberality are construed? In other words, how does one determine what favours the Aboriginal peoples, whose voice matters, and in light of what countervailing consequences?

To the extent the history of Canada's settlement, and the subsequent "special" legal status of Aboriginal peoples in Canada constitute a boundary that demarcates Canada's rule of law claim space, these are the kinds of questions that will remain pertinent in any such case. Such questions reflect not only the meaning of any judicial commitment toward the wellbeing of Aboriginal peoples in Canada, but also the countervailing currents that operate alongside and even in tension with that particular judicial commitment. In the case of statutory interpretation and the rule of law, the boundary metaphor illuminates and helps identify the complex currents that are always at work in any legal interpretive act.

As an illustration, take for example Mitchell v. Peguis Indian Band. ${ }^{143}$ This case concerned an improper sales tax assessed against a group of Aboriginal peoples in Manitoba. The government of Manitoba settled the claims. However, a third-party obtained a pre-judgment garnishment order for having represented the Indians in the settlement process. The Aboriginal litigants sought relief against the garnishment order on various grounds, the most salient of which had to do with ss. 89 and 90 of the Indian Act together. Under these provisions, they argued, personal

\footnotetext{
142 ibid 41.

${ }^{143}$ Mitchell v Peguis Indian Band [1990] 2 SCR 85 [Mitchell].
} 
property conferred to them by the provincial government was deemed to be on a reserve, and therefore was not subject to attachment by a non-Indian. The courts below agreed with the Indians, as did the Supreme Court of Canada. Of particular interest here are the different and distinct arguments used by La Forest J. and Dickson C.J. in their respective opinions. Of the three opinions issued in that judgment, these two reflect very different logics that reveal both the operation of a particular boundary in a Canadian rule of law claim space (i.e., the founding narrative of settlement), and the scope and strength of its operation given the other boundary features of the claim space that operate at the same time (e.g., federalism and the narrative of confederation).

The relevant portions of the Indian Act under consideration in this case read as follows:

87. Notwithstanding any other Act of the Parliament of Canada or any Act of the legislature of a province...the following property is exempt from taxation, namely:

(a) the interest of an Indian or a band in reserve or surrendered lands; and

(b) the personal property of an Indian or band situated on a reserve ...

89(1) Subject to this Act, the real and personal property of an Indian or a band situated on a reserve is not subject to charge, pledge, mortgage, attachment, levy, seizure, distress or execution in favour or at the instance of any person other than an Indian

90(1) For the purposes of sections 87 and 89, personal property that was

(a) purchased by Her Majesty with Indian moneys or moneys appropriated by Parliament for the use and benefit of Indians or bands, or (b) given to Indians or to a band under a treaty or agreement between a band and Her Majesty

shall be deemed always to be situated on a reserve. ${ }^{144}$

Central to the case is whether the phrase "Her Majesty" in s. 90(1) applies only to the federal government or also to the provincial government. For La Forest J., the term only applies to the federal government. Therefore, the deeming provision of s. 90 does not apply to any agreements between a band and a provincial government, and as such a provincial government can order a garnishment in favour of a third-party non-Indian. ${ }^{145}$

\footnotetext{
${ }^{144}$ Indian Act (n 140) (emphasis added).

${ }^{145}$ In this particular case, though, La Forest J. considered the garnishment an end-run around the Indian Act. The original levy of the sales tax was an improper tax on the personal property of an Indian or band "situated on a reserve". Invoking s. 87 of the Indian Act, La Forest J. argued that "it would be truly anomalous if, as a result of the imposition of an ultra vires tax, the application of the provincial law were to impair the ability of the Indians to be placed in the same position as they would have been but for the improper tax". Mitchell (n 143) 148.
} 
In his close reading of s. 90 of the Indian Act, La Forest J. drew upon the bulwark of federalism when he addressed the implications of reading "Her Majesty" broadly to include provincial governments. He noted that elsewhere in the Act, where the provinces are addressed, they are done so expressly. Moreover, he indicated that the Indian Act is a federal act that relates to a matter falling squarely within the federal jurisdiction. As such, "one would expect that an unqualified reference to 'Her Majesty' should be taken as limited to the federal crown." 146

Furthermore, at the heart of ss. 87 and 89 is a protective logic that specifically implicates the federal government in its jurisdiction over Aboriginal affairs. This protective logic interjects "the [federal] Crown between the Indians and the market forces which, if left unchecked, had the potential to erode Indian ownership of these reserve lands." ${ }^{147}$ Whether such market forces are exercised by the provincial government as a major market player or non-indigenous peoples who participate in the market, the point for La Forest $\mathrm{J}$. is that the federal government assumes a unique position to ensure the country's aboriginal peoples have "the untrammelled enjoyment of such advantages as they had retained or might acquire pursuant to the fulfillment of the Crown of its treaty obligations." 148

But in a quick paragraph, La Forest J. interjected an important countervailing consideration that qualifies the scope of that logic of protection in the name of a different rule of law consideration, namely democratic equality. He wrote:

The fact that the modern-day legislation, like its historical counterparts, is so careful to underline that exemptions from taxation and distraint apply only in respect of personal property situated on reserves demonstrates that the purpose of the legislation is not to remedy the economically disadvantaged position of Indians by ensuring that Indians may acquire, hold, and deal with property in the commercial mainstream on different terms than their fellow citizens...Indians who acquire and deal in property outside lands reserved for their use, deal with it on the same basis as all other Canadians. ${ }^{149}$

La Forest J.'s opinion thus far reveals a complex set of boundary conditions. First, the distinctive brand of Canadian federalism informs how to read unqualified phrases in federal legislation concerning a matter falling under federal jurisdiction. Second, the founding narrative of settlement and Aboriginal dispossession undergirds the protection of Aboriginal property on reserve lands, the latter being exceptional spaces carved out of the marketplace in which all other Canadians interact. Third, the citizens to which the government is accountable, and which includes the Aboriginals, participate together in a marketplace that can be both a threat to the Indian's interest in reserve land, and a democratic space in which all

\footnotetext{
${ }^{146}$ Mitchell (n 143) 123.

147 ibid 129-130.

148 ibid 130-131.

149 ibid 131 (emphasis added).
} 
citizens (Aboriginal and otherwise) participate on an equal footing. Indeed, as La Forest J. remarked, outside the reserve system, Indians who have an interest in property "deal with it on the same basis as all other Canadians." ${ }^{150}$ Later in his opinion, he wrote:

When Indian bands enter the commercial mainstream, it is to be expected that they will have occasion from time to time, to enter into purely commercial agreements with the provincial Crowns in the same way as with private interests. The provincial Crowns are, after all, important players in the marketplace. If, then, an Indian band enters into a normal business transaction, be it with a provincial Crown, or a private corporation, and acquires personal property, be it in the form of chattels or debt obligations, how is one to characterize the property concerned? To my mind, it makes no sense to compare it with the property that enures to Indians pursuant to treaties and their ancillary agreements. Indians have a plenary entitlement to their treaty property; it is owed to them qua Indians. Personal property acquired by Indians in normal business dealings is clearly different; it is simply property anyone else might have acquired and I can see no reason why in those circumstances Indians should not be treated in the same way as other people. ${ }^{151}$

In this passage, the market-place and the commercial transactions that occur therein are described as "mainstream", "normal", "purely commercial", and "simply property", and are framed in terms of a larger Canadian citizenry, all of whom presumably ought to have an equal ability to enter into the market place and seek legal redress under the law. The adjectives and phrases italicized in the above quoted paragraph may certainly provoke some to interpret La Forest J. as characterizing the reserve as a peripheral, marginal, even ghettoized economic sphere. However, reading the above language in light of how La Forest J. applied the Nowegijick presumption reveals how his use of "marketplace" is actually a complex proxy for rule of law boundaries concerning founding narratives of settlement, parliamentary sovereignty, federalism, and democratic accountability, all of which operate equally at the same time and none of which he presumed should take priority over the others.

La Forest J. took no issue with the Nowegijick principles of interpretation, but he distinguished how he applied that principle to treaties and to legislation relating to Indians. In the case of treaties, the Nowegijick principles are justified, as a matter of history, by the "fact that the Crown enjoyed a superior bargaining position when negotiating treaties with native peoples. From the perspective of the Indians, treaties were drawn up in a foreign language, and incorporated references to legal concepts of a system of law with which the Indians were unfamiliar." 152 Given that history, justice requires courts to interpret ambiguities as the Indians themselves

\footnotetext{
150 ibid.

151 ibid 138.

152 ibid 142-3.
} 
would have understood the terms. In other words, the founding narrative of settlement frames how treaties with the Aboriginal peoples ought to be interpreted.

Statutes, on the other hand, "are an expression of the will of Parliament" and thereby elicit respect for parliamentary sovereignty as a boundary condition. ${ }^{153}$ As expressions of Parliament, statutes must be construed in terms that respect Parliament's sovereign responsibility across its domain. Consequently, La Forest J. would construe statutes relating to Indians "with a view to elucidating what it was that Parliament wished to effect in enacting the particular section in question." 154

Furthermore, La Forest J. pointed out that at issue in this case was a conflict between Manitoba's Garnishment Act and the federal Indian Act. As such, the founding narrative of Confederation - and thus the federalism it enabled - must also inform how one both reads the federal Indian Act, and accounts for the implications a broad reading might have on provincial governments. As La Forest J. mentioned:

$[\mathrm{P}]$ rovincial Crowns bear no responsibility to provide for the welfare and protection of native peoples, and I am not prepared to accept that Parliament, in enacting s. 90(1)(b), intended that the privileges of ss. 87 and 89 exempt Indian bands from taxation and civil process in respect of all personal property that they may acquire pursuant to all agreements with that level of government. $^{155}$

Indeed, his respect for the fortifying force of federalism arguably led La Forest J. to challenge Dickson C.J.'s application of the Nowegijick principle by which the latter argued from the Indian perspective that the federal-provincial distinction would not matter. As Dickson C.J. wrote: "From the aboriginal perspective, any federal-provincial divisions that the Crown has imposed on itself are internal to itself and do not alter the basic structure of Sovereign-Indian relations." ${ }^{156}$ In other words, what federalism implies for this case depends on how one reads Canadian history and relates (or not) the parallel and, in important ways, overlapping narratives of settlement and Confederation.

For La Forest J., even if Dickson C.J. were right, assuming an Aboriginal perspective ought not create an expectation interest on the part of Aboriginal peoples about special protections in the marketplace that would give them an advantage over other market participants. According to La Forest J., "it does not follow that fairness requires one to proceed on the basis that Indians would be justified in concluding that all property they may acquire pursuant to agreements with that 'indivisible entity' should be automatically protected... Thus I take it that Indians, when engaging in the cut and thrust of business dealings in the

\footnotetext{
153 ibid 143.

154 ibid 143.

155 ibid 143-4.

156 ibid 109.
} 
commercial mainstream are under no illusions that they can expect to compete from a position of privilege with respect to their fellow Canadians." ${ }^{157}$ La Forest J.'s language about "fairness", "mainstream", "position of privilege", and "fellow Canadians" connotes a certain concern with equality, access, and democratic accountability. Moreover, that concern with equality cuts both ways, according to La Forest J. He argued that a broad reading of "Her Majesty" would actually work against the interests of Indians and even preclude them from effective entry into the mainstream marketplace, or in other words preclude them from the larger demos to which Parliament is responsible when legislating. "I think it safe to say," he wrote, "that businessmen place a great premium on certainty in their commercial dealings, and that, accordingly, the greatest possible incentive to do business with Indians would be the knowledge that business may be conducted with them on exactly the same basis as with any other person." 158

In his opinion, Dickson C.J. did not simply ignore the role of democracy, federalism, or parliamentary sovereignty in the case. Rather, he seemed to engage them from the perspective of the "Court's sensitivity to the historical and continuing status of aboriginal peoples in Canadian society." 159 In other words, the founding narrative of settlement framed for Dickson C.J. the responsibility not only of the Court and the government toward Canada's Aboriginal peoples, but also of the entire Canadian populace: "It is Canadian society at large which bears the historical burden of the current situation of native peoples...Underlying Nowegijick is an appreciation of societal responsibility and a concern with remedying disadvantage, if only in the somewhat marginal context of treaty and statutory interpretation." 160 In this brief passage, Dickson C.J. resolved La Forest J.'s democratic concerns about equality and the marketplace by undercutting La Forest J.'s presumption that such equality exists (or is possible) for all Canadians. Dickson C.J. invoked the founding narrative of settlement as a boundary condition in order to explain why "Her Majesty" in s. 90 of the Indian Act includes the provincial government. Invoking the Nowegijick principle, Dickson C.J. adopted a reading of "Her Majesty" that favoured the Aboriginal litigants in the case. This principle informed how he resolved concerns about federalism and provincial parliamentary sovereignty. Referring to an "aboriginal understanding" of the phrase "Her Majesty", he doubted they would distinguish between federal and provincial governments. Specifically, he wrote: "the Indians' relationship with the Crown or sovereign has never depended on the particular representatives of the Crown involved. From the aboriginal perspective, any federal-provincial divisions

\footnotetext{
157 ibid 144-5 (italics added).

158 ibid 147 (emphasis added).

159 ibid 99

160 ibid 99. Dickson C.J.'s biographers note that given his experiences in Manitoba with aboriginal peoples, it is not surprising that he would take the above position on Canada's larger responsibility toward its aboriginal peoples. See R.J. Sharpe and K. Roach, Brian Dickson: A Judge's Journey (University of Toronto Press, Toronto 2003) chapter 21.
} 
that the Crown has imposed on itself are internal to itself and do not alter the basic structure of Sovereign-Indian relations." 161

The founding narrative of settlement also informed Dickson C.J.'s discussion of s. 88 of the Indian Act, which recognizes that provincial legislation can and will affect Indians under the Indian Act. That section provides:

Subject to the terms of any treaty and any other Act of Parliament, all laws of general application from time to time in force in any province are applicable to and in respect of Indians in the province, except to the extent that those laws are inconsistent with this Act or any order, rule, regulation or by-law made thereunder, and except to the extent that those laws make provision for any matter for which provision is made by or under this Act. ${ }^{162}$

There was no doubt for him that provincial legislation can affect Canada's aboriginal peoples no more or less than any other citizen. Indeed, "[a]s long as Indians are not affected qua Indians, a provincial law may affect Indians, and significantly so in terms of everyday life."163 But his respect for provincial parliamentary sovereignty was counter-balanced by his interest in upholding the federal government's protective role of its aboriginal peoples. Section 88 of the Indian Act, therefore, does not insulate provincial legislation nor does it over-ride it in the name of an over-bearing federal government. Rather, for Dickson C.J., this section of the Indian Act reflects what he called a "fluidity of responsibility across lines of jurisdiction". ${ }^{164}$ Fluidity here captured Dickson C.J.'s respect for the sovereignty of provincial legislative assemblies; support for the protective role of the federal government; and recognition that Indians must receive the kinds of protections due to them as a specific group that has a unique history for which all of Canada must take responsibility.

When addressing the Nowegijik principle and whether it is invoked narrowly only in the presence of an ambiguity or broadly even in the absence of one, Sullivan advocated a broad reading. She said: "the liberal construction of legislation relating to Aboriginal peoples is in part an attempt to remedy injustice resulting from the Crown's past failures to live up to its commitments and to discharge its fiduciary responsibilities. From this perspective, there is no justification for treating it as a presumption of last resort." 165 From a rule of law perspective, as utilized herein, Sullivan's position can be read in two different ways. The first prioritizes the founding narrative of settlement over and against all others features that equally constitute the boundary of Canada's rule of law claim space. The second views all the other boundary conditions from a vantage point of the founding narrative of settlement. In either case, the various boundary

\footnotetext{
${ }^{161}$ Mitchell (n 143) 109.

162 Indian Act (n 140).

${ }^{163}$ Mitchell (n 143) 109.

164 ibid 109.

165 Sullivan (n 13) 513.
} 
conditions of a Canadian rule of law claim space are either trumped or viewed in derivative fashion. As much as her position accords with Dickson C.J.'s opinion in Peguis Indian Band, La Forest J.'s opinion runs contrary. Both opinions implicitly invoked the boundaries that delineate the rule of law claim space within which both justices once sat. Both agreed that the Court must play a role in resolving a dispute that affects Aboriginal peoples who fall under the Indian Act. Both recognized the symbolic, historic, and legal significance of the Nowegijick interpretive presumptions. Where they differed was in how that presumption comingles with the others that are always and at all times present in any legal analysis. Federalism, parliamentary sovereignty, democratic accountability, and responsibility for the affairs of a people dispossessed by the very creation of Canada operated together at the same time in Mitchell v Peguis Indian Band to reveal the complex boundary functions of a distinctively Canadian rule of law claim space.

\section{E. CONCLUSIONS}

At the heart of this article has been an interest in giving content to rule of law as an analytic concept. This interest operates amid considerable scepticism about rule of law as a coherent concept, and concerns that it all too often serves as selfcongratulatory political cover, or even more, as cover for neo-colonial ventures in the developing world. ${ }^{166}$ In one sense, it might be prudent to avoid recourse to the term entirely. Indeed, other terms of art might be less controversial, such as "legality". But the absence of controversy or scepticism does not imply greater analytic content. Indeed, to substitute words is merely to change the linguistic container, not to fill it with content. And as a scholar whose work involves the study of medieval legal history and contemporary statutory interpretation, as well as participation in rule of law and development projects, this author remains painfully cognizant of the near omnipresence of "rule of law", whether as a slogan, a catchphrase, or a programmatic endeavour across a wide range of polities and societies. Reading this phrase through the literature on legal interpretation, however, imports into the rule of law analysis questions of determinacy, subjectivity, and context. In doing so, I have argued that history (broadly construed in both diachronic and synchronic terms) offers an important disciplinary contribution to a range of philosophical analysis that can both give heft to rule of law analytically, and limit its presumed transportability and scope of unqualified application.

Greater historical attention in rule of law debates puts into stark relief the various conditions that render certain sources as legal sources; certain arguments as legal arguments; certain institutions as legal institutions. Those conditions constitute the boundaries of rule of law as a claim space, within which arguments about law are made. The analytic heft of rule of law, when viewed as a claim space, is meant to draw our attention to the boundaries that define, demarcate, and delineate the claim space of a rule of law tradition. Boundaries, in this context, are

${ }^{166}$ See Shklar (n 4); Humphreys (n 7). 
important tropes. They include and, perhaps most poignantly, they also exclude in a gesture of protection. They permit movement back and forth, in and out. They are also on the periphery, and as such are often so taken for granted as to be unaccounted for despite their salience. As this article has suggested, the field of statutory interpretation offers a window from which to view those boundaries in greater detail. The presumptions of statutory interpretation, on this reading, are proxies for these boundary conditions that enable, animate and even limit legal argument.

Of course, one may find the heftiness of this account of rule of law lacking. Far from giving more robust, or even moderately determinate content to rule of law, the model advocated herein remains conceptually thin. If rule of law is a claim space whose boundaries attest to the particularity of a legal tradition, one might plausibly argue that those boundaries reflect a rigid institutional formalism. Indeed, that is certainly one way to read the Iacobucci and Cory JJ. concurrence in Baker v Canada

To be clear, it is not the case that the boundary conditions are particularly deep philosophical concepts. They are presumptions that reflect key values that keep within the realm of legality what matters, keep out what undercuts a particular tradition of legality, and permit border crossings when there is good reason to give something admission or remove something from consideration. Most notably, though, these borders are pitched quite far away from the center of most important controversies - they are presumed to exist, in the same way that those living in Vancouver, Toronto, Montreal, and St. John presume that there is a border dividing the US and Canada, but do not actually see it with their own eyes. They know it is there. They know it so well and so deeply that they may not even think much about it. Indeed, that sense in which boundaries are always already there speaks to the presumptive, implicit contribution boundary conditions make to the analytic heft of rule of law. When what is always already there is brought into the foreground, we can more robustly and responsibly reflect on what it represents, how it relates to other boundary features, and what these boundary conditions in the aggregate imply about controversies taking place at the center, in courtrooms across the country. 